\title{
Batch extraction method to estimate total dissolved solids (TDS) release from coal refuse and overburden ${ }^{\text {is }}$
}

\author{
L.E. Castillo-Meza ${ }^{\mathrm{a}, \mathrm{b}}$, C.A. Cravotta ${ }^{\mathrm{c}}$, T.L. Tasker ${ }^{\mathrm{a}, \mathrm{d}}$, N.R. Warner ${ }^{\mathrm{a}}$, W.L. Daniels ${ }^{\mathrm{e}}$, Z.

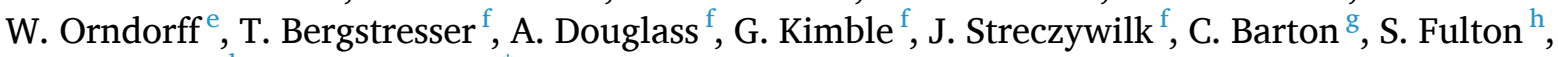 \\ A. Thompson ${ }^{\mathrm{h}}$, W.D. Burgos ${ }^{\text {a, * }}$

\footnotetext{
a Department of Civil and Environmental Engineering, The Pennsylvania State University, 212 Sackett Building, University Park, PA, 16802, United States

${ }^{\mathrm{b}}$ Department of Environmental Engineering, Universidad Pontificia Bolivarina, Bucaramanga, Colombia

${ }^{\text {c }}$ U.S. Geological Survey, 215 Limekiln Rd., New Cumberland, PA, 17070, United States

d Department of Environmental Engineering, Saint Francis University, 117 Evergreen Drive, Loretto, PA, 15940, United States

${ }^{\mathrm{e}}$ School of Plant \& Environmental Sciences, 0404, Virginia Tech, Blacksburg, VA, 24061, United States

${ }^{\mathrm{f}}$ Geochemical Testing, $2005 \mathrm{~N}$ Center Ave, Somerset, PA, 15501, United States

${ }^{g}$ Department of Forestry and Natural Resources, University of Kentucky, 203 Thomas Poe Cooper Building, Lexington, KY, 40546, United States
} \\ ${ }^{\mathrm{h}}$ Department of Crop and Soil Sciences, University of Georgia, 3111 Miller Plant Sciences Building, Athens, GA, 30602, United States
}

\section{A R T I C L E I N F O}

Editorial handling by Dr T. H. Darrah

\section{Keywords:}

Coal mining

Salinization

Reclamation

\begin{abstract}
A B S T R A C T
A rapid batch extraction method was evaluated to estimate potential for total dissolved solids (TDS) release by 65 samples of rock from coal and gas-bearing strata of the Appalachian Basin in eastern USA. Three different extractant solutions were considered: deionized water (DI), DI equilibrated with $10 \% \mathrm{CO}_{2}$ atmosphere (DI $\left.\mathrm{CO}_{2}\right)$, or $30 \% \mathrm{H}_{2} \mathrm{O}_{2}$ under $10 \% \mathrm{CO}_{2}\left(\mathrm{H}_{2} \mathrm{O}_{2} \quad \mathrm{CO}_{2}\right)$. In all extractions, $10 \mathrm{~g}$ of pulverized rock $(<0.5$-mm) were mixed with $20 \mathrm{~mL}$ of extractant solution and shaken for $4 \mathrm{~h}$ at $50 \mathrm{rpm}$ and 20-22 C. The 65 rock samples were classified as coal (n 3), overburden (n 17), coal refuse that had weathered in the field (n 14), unleached coal refuse that had oxidized during indoor storage (n 20 ), gas-bearing shale ( $n \quad 10)$, and pyrite (n 1 ). Extracts were analyzed for specific conductance (SC), TDS, $\mathrm{pH}$, and major and trace elements, and subsequently speciated to determine ionic contributions to SC. The $\mathrm{pH}$ of extractant blanks decreased in the order DI (6.0), DI $\mathrm{CO}_{2}$ (5.1), and $\mathrm{H}_{2} \mathrm{O}_{2} \quad \mathrm{CO}_{2}$ (2.6). The DI extractant was effective for mobilizing soluble $\mathrm{SO}_{4}$ and $\mathrm{Cl}$ salts. The DI $\mathrm{CO}_{2}$ extractant increased weathering of carbonates and resulted in equivalent or greater TDS than the DI leach of the same material. The $\mathrm{H}_{2} \mathrm{O}_{2} \quad \mathrm{CO}_{2}$ extractant increased weathering of sulfides (and carbonates) and resulted in the greatest TDS production and lowest $\mathrm{pH}$ values. Of the 65 samples, 19 had leachate chemistry data from previous column experiments and 35 were paired to 10 field sites with leachate chemistry data. When accounting for the water-to-rock ratio, TDS from DI and DI $\mathrm{CO}_{2}$ extractions were correlated to TDS from column experiments while TDS from $\mathrm{H}_{2} \mathrm{O}_{2} \quad \mathrm{CO}_{2}$ extractions was not. In contrast to column experiments, field SC was better correlated to $\mathrm{SC}$ measured from $\mathrm{H}_{2} \mathrm{O}_{2} \quad \mathrm{CO}_{2}$ extractions than DI extractions. The field SC and SC from $\mathrm{H}_{2} \mathrm{O}_{2} \quad \mathrm{CO}_{2}$ extractions were statistically indistinguishable for 7 of 9 paired data sets while SC from DI extractions underestimated field SC in 5 of 9 cases. Upscaling comparisons suggest that (1) weathering reactions in the field are more aggressive than DI water or synthetic rainwater extractants used in batch or column tests, and (2) a batch extraction method utilizing $30 \% \mathrm{H}_{2} \mathrm{O}_{2}$ (which is mildly acidic without $\mathrm{CO}_{2}$ enrichment) could be effective for identifying rocks that will release high amounts of TDS.
\end{abstract}

\section{Introduction}

High salinity in streams downgradient of coal-mining and processing facilities in the eastern United States (U.S.) has caused fish kills and harmed sensitive aquatic organisms within the past decade (Barrett, 2015; Cormier et al., 2013a,b; Pond et al., 2008). At the same time,

\footnotetext{
H Prepared for submission to Applied Geochemistry.

* Corresponding author.

E-mail address: wdb3@psu.edu (W.D. Burgos).
} 
Table 1

Descriptions of the 65 rock samples tested.

\begin{tabular}{|c|c|c|c|c|c|c|c|c|}
\hline ID & Source $^{a}$ & $\begin{array}{l}\text { Operational Rock } \\
\text { Type }^{\text {b }}\end{array}$ & Lithology & $\mathbf{W E} \mathbf{E}^{\mathrm{c}}$ & $\begin{array}{l}\text { Stratigraphic } \\
\text { Formation }\end{array}$ & $\begin{array}{l}\text { Local Geologic } \\
\text { Description }\end{array}$ & Mineralogy ${ }^{\mathrm{d}}$ & $\begin{array}{l}\text { Data for } \\
\text { Upscaling }\end{array}$ \\
\hline PA1 & Mine A & Coal & Coal & $\mathrm{W}$ & Kittanning & L. Kittanning & Qtz, Cal, Kln, Py, Ms & n.a. ${ }^{\mathrm{f}}$ \\
\hline PA5 & Mine A & Coal & Coal & $\mathrm{W}$ & Kittanning & L. Kittanning & Qtz, Kln, Py, Ms & n.a. \\
\hline PA45 & Mine B & Coal & Coal & $\mathrm{W}$ & $\begin{array}{l}\text { Kittanning and } \\
\text { Allegheny }\end{array}$ & $\begin{array}{l}\text { L. Kittanning/U. } \\
\text { Kittanning/Freeport }\end{array}$ & Qtz, Kln, Jr, Ms & n.a. \\
\hline PA12 & Mine A & W. Refuse & $\begin{array}{l}\text { Coal and } \\
\text { shale }\end{array}$ & $\mathrm{W}$ & Kittanning & L. Kittanning & Qtz, Gp, Kln, Ms, Jr, & FL \\
\hline PA13 & Mine A & W. Refuse & $\begin{array}{l}\text { Coal and } \\
\text { shale }\end{array}$ & $\mathrm{W}$ & Kittanning & L. Kittanning & Qtz, Gp, Kln, Ms, Jr, & FL \\
\hline PA17 & Mine A & W. Refuse & $\begin{array}{l}\text { Coal and } \\
\text { shale }\end{array}$ & $\mathrm{W}$ & Kittanning & L. Kittanning & Qtz, Kln, Ms, Py, & FL \\
\hline PA22 & Mine A & W. Refuse & $\begin{array}{l}\text { Coal and } \\
\text { shale }\end{array}$ & $\mathrm{W}$ & Kittanning & L. Kittanning & Qtz, Ms, Kln, Py, Gp, Vrm & FL \\
\hline PA30 & Mine A & W. Refuse & $\begin{array}{l}\text { Coal and } \\
\text { shale }\end{array}$ & $\mathrm{W}$ & Kittanning & L. Kittanning & Qtz, Cal, Kln, Py, Ms, Gp & FL \\
\hline PA31 & Mine B & W. Refuse & $\begin{array}{l}\text { Coal and } \\
\text { shale }\end{array}$ & $\mathrm{W}$ & $\begin{array}{l}\text { Kittanning and } \\
\text { Allegheny }\end{array}$ & $\begin{array}{l}\text { L. Kittanning/U. } \\
\text { Kittanning/Freeport }\end{array}$ & Qtz, Gp, Ms, Kln, Py, Cal, Vrm & FL \\
\hline PA36 & Mine B & W. Refuse & $\begin{array}{l}\text { Coal and } \\
\text { shale }\end{array}$ & $\mathrm{W}$ & $\begin{array}{l}\text { Kittanning and } \\
\text { Allegheny }\end{array}$ & $\begin{array}{l}\text { L. Kittanning/U. } \\
\text { Kittanning/Freeport }\end{array}$ & Qtz, Kln, Ms, Py, Vrm & FL \\
\hline PA42 & Mine B & W. Refuse & $\begin{array}{l}\text { Coal and } \\
\text { shale }\end{array}$ & $\mathrm{W}$ & $\begin{array}{l}\text { Kittanning and } \\
\text { Allegheny }\end{array}$ & $\begin{array}{l}\text { L. Kittanning/U. } \\
\text { Kittanning/Freeport }\end{array}$ & Qtz, Klm, Ms, Gp, Vrm & FL \\
\hline PA48 & Mine B & W. Refuse & $\begin{array}{l}\text { Coal and } \\
\text { shale }\end{array}$ & $\mathrm{W}$ & $\begin{array}{l}\text { Kittanning and } \\
\text { Allegheny }\end{array}$ & $\begin{array}{l}\text { L. Kittanning/U. } \\
\text { Kittanning/Freeport }\end{array}$ & Qtz, Ms, Kln, Gp, Py, Vrm & FL \\
\hline PA51 & Mine B & W. Refuse & $\begin{array}{l}\text { Coal and } \\
\text { shale }\end{array}$ & $\mathrm{W}$ & $\begin{array}{l}\text { Kittanning and } \\
\text { Allegheny }\end{array}$ & $\begin{array}{l}\text { L. Kittanning/U. } \\
\text { Kittanning/Freeport }\end{array}$ & Qtz, Ms, Kln, Gp, Vrm & FL \\
\hline PA58 & Mine B & W. Refuse & $\begin{array}{l}\text { Coal and } \\
\text { shale }\end{array}$ & $\mathrm{W}$ & $\begin{array}{l}\text { Kittanning and } \\
\text { Allegheny }\end{array}$ & $\begin{array}{l}\text { L. Kittanning/U. } \\
\text { Kittanning/Freeport }\end{array}$ & Qtz, Ms, Kln, Gp, Jr, Vrm & FL \\
\hline TNR1 & VT & W. Refuse & n.a. & n.a. & Graves Gap & Graves Gap refuse & Qtz, Ms, Kln, Vrm & CL \\
\hline TNR2 & VT & W. Refuse & n.a. & n.a. & Graves Gap & Graves Gap refuse & Qtz, Cal, Ms, Kln, Gp, Vrm & CL \\
\hline TNR3 & VT & W. Refuse & n.a. & n.a. & Graves Gap & Graves Gap refuse & Qtz, Ms, Kln, Vrm, Py & CL \\
\hline TGS1 & PA & U. Refuse & $\begin{array}{l}\text { Coal and } \\
\text { shale }\end{array}$ & $\mathrm{U}$ & Monongahela & Pittsburgh & Qtz, Py, Kln, Ms, Vrm & FL \\
\hline TGS2A & PA & U. Refuse & $\begin{array}{l}\text { Coal and } \\
\text { shale }\end{array}$ & $\mathrm{U}$ & Monongahela & Pittsburgh & Qtz, Poi, Py, Kln & n.a. \\
\hline TGS2B & PA & U. Refuse & $\begin{array}{l}\text { Coal and } \\
\text { shale }\end{array}$ & $\mathrm{U}$ & Monongahela & Pittsburgh & Qtz, Kln, Ms & FL \\
\hline TGS3 & PA & U. Refuse & Claystone & $\mathrm{U}$ & Monongahela & Pittsburgh & Qtz, Cal, Kln, Ms, Py & FL \\
\hline TGS4 & PA & U. Refuse & Shale & $\mathrm{U}$ & Monongahela & Pittsburgh & Qtz, Kln, Ms, Vrm & n.a. \\
\hline TGS5 & PA & U. Refuse & $\begin{array}{l}\text { Coal and } \\
\text { shale }\end{array}$ & $\mathrm{U}$ & Monongahela & Pittsburgh & Qtz, Poi, Py, Kln & FL \\
\hline TGS6 & PA & U. Refuse & Shale & $\mathrm{U}$ & Monongahela & Pittsburgh & Qtz, Kln, Ms & FL \\
\hline TGS7A & PA & U. Refuse & Claystone & $\mathrm{U}$ & Monongahela & Pittsburgh & Qtz, Cal, Ms, Kln & FL \\
\hline TGS7B & PA & U. Refuse & Claystone & $\mathrm{U}$ & Monongahela & Pittsburgh & Qtz, Kln, Py, Ms & FL \\
\hline TGS8 & PA & U. Refuse & $\begin{array}{l}\text { Coal and } \\
\text { shale }\end{array}$ & $\mathrm{U}$ & Monongahela & Pittsburgh & Qtz, Kln, Ms,Poi, Rz & FL \\
\hline TGS9 & PA & U. Refuse & Shale & $\mathrm{U}$ & Monongahela & Pittsburgh & Qtz, Kln, Ms & FL \\
\hline TGS10A & PA & U. Refuse & $\begin{array}{l}\text { Coal and } \\
\text { shale }\end{array}$ & $\mathrm{U}$ & Monongahela & Pittsburgh & Qtz, Rz, Kln, Py, Ms & n.a. \\
\hline TGS10B & PA & U. Refuse & $\begin{array}{l}\text { Coal and } \\
\text { shale }\end{array}$ & $\mathrm{U}$ & Monongahela & Pittsburgh & Qtz, Kln, Ms, Rz & FL \\
\hline TGS11 & PA & U. Refuse & Shale & $\mathrm{U}$ & Monongahela & Pittsburgh & Qtz, Kln, Ms & FL \\
\hline TGS12 & PA & U. Refuse & Shale & $\mathrm{U}$ & Monongahela & Pittsburgh & Qtz, Gp, Py, Kln, Ms & FL \\
\hline TGS13 & PA & U. Refuse & Shale & $\mathrm{U}$ & Monongahela & Pittsburgh & Cal, Qtz, Kln & FL \\
\hline ID & $\mathbf{S M}^{\mathrm{a}}$ & $\begin{array}{l}\text { Operational Rock } \\
\text { Type }^{\text {b }}\end{array}$ & Lithology & $\mathbf{W E}^{\mathrm{c}}$ & $\begin{array}{l}\text { Stratigraphic } \\
\text { Formation }\end{array}$ & $\begin{array}{l}\text { Local Geologic } \\
\text { Description }\end{array}$ & Mineralogy $^{\mathrm{d}}$ & $\begin{array}{l}\text { Data for } \\
\text { Upscaling }\end{array}$ \\
\hline TGS14 & PA & U. Refuse & $\begin{array}{l}\text { Coal and } \\
\text { shale }\end{array}$ & $\mathrm{U}$ & Monongahela & Pittsburgh & Qtz, Ms, Klm, Py, Vrm & FL \\
\hline TGS15 & PA & U. Refuse & Claystone & $\mathrm{U}$ & Monongahela & Pittsburgh & Qtz, Klm, Ms, Py & FL \\
\hline TGS16 & PA & U. Refuse & Claystone & $\mathrm{U}$ & Monongahela & Pittsburgh & Qtz, Py, Klm, Ms & FL \\
\hline TGS17 & PA & U. Refuse & Claystone & $\mathrm{U}$ & Monongahela & Pittsburgh & Qtz, Klm, Ms, Cal, Py & FL \\
\hline BCS3 & USGS & Overburden & Shale & $\mathrm{U}$ & Glenshaw & Brush Creek shale & $\begin{array}{l}\text { Qtz, Ms, Kln, Chl, Vrm, Cal, } \\
\text { Py }\end{array}$ & CL, FL \\
\hline HCS & USGS & Overburden & Shale & $\mathrm{U}$ & Carbondale & Houchin Creek shale & $\begin{array}{l}\text { Qtz, Gp, Ms, Ill, Chl, Kln, Jr, } \\
\text { Py, Ab, Vrm }\end{array}$ & CL \\
\hline KBFWV & USGS & Overburden & Shale & $\mathrm{U}$ & Kanawha & Black Flint shale & Qtz, Kln, Ms, Dol, Sd, Ab, Vrm & CL \\
\hline LKFC & USGS & Overburden & Shale & $\mathrm{U}$ & Kittanning & L. Kittanning & $\begin{array}{l}\text { Qtz, Ms, Chl, Ill, Kln, Vrm, } \\
\text { Gp, Py, Sd }\end{array}$ & CL, FL \\
\hline MKSS & USGS & Overburden & Sandstone & $\mathrm{U}$ & Kittanning & M. Kittanning & $\begin{array}{l}\text { Qtz, Ms, Kln, Chl, Vrm, Gp, } \\
\text { Cal, Sd }\end{array}$ & $\mathrm{CL}$ \\
\hline KY1 & UK & Overburden & Sandstone & $\mathrm{W}$ & Princess & Princess & Qtz, Kln, Vrm, Dol, Sd, Gt & CL, FLY \\
\hline KY2 & UK & Overburden & Sandstone & $\mathrm{U}$ & Four Corners & Four Corners & Qtz, Kln, Vrm, Dol, Sd & CL, FLY \\
\hline KY3 & UK & Overburden & Mixed & $\mathrm{W}$ & Four Corners & Four Corners & Qtz, Kln, Vrm, Dol, Sd, Gt & CL, FLY \\
\hline KY4 & UK & Overburden & Mixed? & $\mathrm{U}$ & Four Corners & Four Corners & Qtz, Kln, Vrm & CL \\
\hline
\end{tabular}


Table 1 (continued)

\begin{tabular}{|c|c|c|c|c|c|c|c|c|}
\hline ID & Source $^{a}$ & $\begin{array}{l}\text { Operational Rock } \\
\text { Type }^{\text {b }}\end{array}$ & Lithology & $\mathbf{W E}^{\mathrm{c}}$ & $\begin{array}{l}\text { Stratigraphic } \\
\text { Formation }\end{array}$ & $\begin{array}{l}\text { Local Geologic } \\
\text { Description }\end{array}$ & Mineralogy & $\begin{array}{l}\text { Data for } \\
\text { Upscaling }\end{array}$ \\
\hline KY7 & VT & Overburden & Mixed & $\mathrm{U}$ & Four Corners & Four Corners black shale & Qtz, Ms, Kln, Ab, Gp, Vrm & CL, FL \\
\hline KY9 & VT & Overburden & Mixed & $\mathrm{U}$ & Four Corners & Four Corners mixed & Qtz, Ms, Kln, Vrm & CL \\
\hline TN2 & VT & Overburden & Shale mix & n.a. & $\begin{array}{l}\text { Anderson and Glen } \\
\text { Dean }\end{array}$ & $\begin{array}{l}\text { Windrock, Lower Dean, } \\
\text { Dean }\end{array}$ & n.a. & CL \\
\hline VA2 & VT & Overburden & Black shale & $\mathrm{U}$ & Four Corners & Four Corners black shale & Qtz, Ms, Kln, Vrm & CL \\
\hline VA3 & VT & Overburden & Mixed & $\mathrm{U}$ & Wise & M. Wise mixed & Qtz, Ms, Kln, Ab, Vrm & CL \\
\hline VA6 & VT & Overburden & Mudstone & $\mathrm{U}$ & Wise & Lower Wise mudstones & Qtz, Ms, Kln, Vrm & n.a. \\
\hline VA16 & VT & Overburden & Sandstone & $\mathrm{U}$ & Harlan & Harlan Sandstone & Qtz, Ms, Kln, Vrm & CL \\
\hline WV5 & VT & Overburden & Sandstone & $\mathrm{U}$ & Kanawha & Kanawha Sandstone & Qtz, Ms, Kln, Vrm & CL \\
\hline SHJ1 & NDA & Shale & Shale gas & $\mathrm{U}$ & Utica & Utica Shale & $\begin{array}{l}\text { Qtz, Cal, Ms, Kln, Dol, Py, } \\
\text { Vrm }\end{array}$ & n.a. \\
\hline SHJ2 & NDA & Shale & Shale gas & $\mathrm{U}$ & Utica & Utica Shale & $\begin{array}{l}\text { Qtz, Cal, Ms, Kln, Dol, Py, } \\
\text { Vrm }\end{array}$ & n.a. \\
\hline SHJ3 & NDA & Shale & Shale gas & $\mathrm{U}$ & Utica & Utica Shale & $\begin{array}{l}\text { Qtz, Cal, Ms, Kln, Dol, Py, } \\
\text { Vrm }\end{array}$ & n.a. \\
\hline SHJ4 & NDA & Shale & Shale gas & $\mathrm{U}$ & Utica & Utica Shale & $\begin{array}{l}\text { Qtz, Cal, Ms, Kln, Dol, Py, } \\
\text { Vrm }\end{array}$ & n.a. \\
\hline SHJ5 & NDA & Shale & Shale gas & $\mathrm{U}$ & Utica & Utica Shale & $\begin{array}{l}\text { Qtz, Cal, Ms, Kln, Dol, Py, } \\
\text { Vrm }\end{array}$ & n.a. \\
\hline SHM1 & NDA & Shale & Shale gas & $\mathrm{U}$ & Utica & Utica Shale & Qtz, Kln, Ms, Dol, Py & n.a. \\
\hline SHM2 & NDA & Shale & Shale gas & $\mathrm{U}$ & Utica & Utica Shale & Qtz, Kln, Ms, Dol, Py & n.a. \\
\hline SHM3 & NDA & Shale & Shale gas & $\mathrm{U}$ & Utica & Utica Shale & n.a. & n.a. \\
\hline SHO1 & $\mathrm{OH}$ & Shale & Shale gas & $\mathrm{U}$ & Utica & Utica Shale & $\begin{array}{l}\text { Qtz, Cal, Ms, Kln, Vrm, Py, } \\
\text { Dol }\end{array}$ & n.a. \\
\hline SHE1 & PA & Shale & Shale gas & $\mathrm{U}$ & Marcellus & Marcellus Shale & Qtz, Cal, Ms, Kln, Vrm, Gp, Py & n.a. \\
\hline SKYPA & USGS & Pyrite & Pyrite & n.a. & Bald Eagle & Bald Eagle Sandstone & Qtz, Ms, Py & FR \\
\hline
\end{tabular}

${ }^{\text {a }}$ Source: OH Ohio Geologic Survey; NDA Penn State Non-disclosure agreement; PA Pennsylvania Bureau of Topographic and Geologic Survey; USGS U.S. Geological Survey; UK University of Kentucky; VT Virginia Tech.

${ }^{\mathrm{b}} \mathrm{U}$. Refuse Unleached refuse; W. Refuse Weathered refuse.

${ }^{c}$ WE Weathering extent: U Unweathered (partly oxidized while stored indoors but unleached); W Weathered (partly oxidized and leached outdoors).

${ }^{\mathrm{d}}$ Minerals identified by XRD and are listed in semi-quantitative order of abundance. Ab albite; Cal calcite; Chl chlorite; Dol dolomite; Gp gypsum; Gt goethite; Ill illite; Jr jarosite; Kln Kaolinite; Ms muscovite; Poi poitevinite; Py pyrite; Qtz quartz; Rz rozenite; Sd siderite; Vrm vermiculite.

e CL Column leachate; FL Field leachate; FLY Field lysimeter; FR Field runoff.

${ }^{\mathrm{f}}$ n.a. not available.

higher than normal concentrations of total dissolved solids (TDS), chloride, and bromide have been documented in the Allegheny and Monongahela Rivers in western Pennsylvania (Wang, 2014; Ziemkiewicz, 2015a), while a gradual increase in salinity attributed to chloride has been documented in major rivers in the northeastern U.S. (Kaushal et al., 2005, 2018). Such observations for coal-mine drainage in the northern Appalachian Basin may be explained by recent changes in resource extraction activities that can be influenced by residual brine in the rock, including the underground mining of coal into progressively deeper zones, the development of coal-bed methane, and the development of shale gas reserves in strata below the coal-bearing formations, notably the Marcellus Shale (Cravotta and Brady, 2015; Donovan and Leavitt, 2004; Donovan et al., 2015; Ziemkiewicz, 2015a). An understanding of the potential sources of salinity at local and watershed scales is necessary for the development of effective strategies to minimize and mitigate aquatic impacts from elevated TDS.

Accelerated mineral weathering generally accounts for increased TDS release from coal-mining landscapes (Brady et al., 1998; Timpano et al., 2010, 2015). Although acidic drainage and TDS release are commonly attributed to abandoned mines, the use of overburden materials as topsoil substitutes and the placement of carbonate-bearing overburden materials can contribute to elevated TDS (Bernhardt et al., 2012; Cormier et al., 2013a,b; Zipper et al., 2015). Topsoil substitution with overburden is explicitly allowed in the Surface Mining Control and Reclamation Act (SMCRA), and the application of acid-base accounting (ABA) procedures guides placement of alkaline strata with the explicit goal of decreasing acidity from sulfide oxidation (Skousen et al., 2002). Oxidative dissolution of sulfide minerals will release dilute sulfuric acid, iron, and other metal(loids). Subsequent neutralization of sulfuric acid by carbonate minerals, used in ABA to balance acid generation, results in the release of calcium, magnesium, and bicarbonate. Although silicate mineral weathering rates are slower than those of carbonates, silicates predominate in coal overburden and can be major sources of calcium, magnesium, sodium, potassium, aluminum, and silicon (Brady et al., 1998; Clark et al., 2018; Hammarstrom et al., 2009). Dissolution of salts or in situ brines retained in the rock also releases sodium, calcium, sulfate, and chloride (as well as, barium, strontium, and bromide).

Laboratory-scale column and mesocosm-scale lysimeter experiments have been used to predict TDS release from coal industry materials (overburden, refuse, combustion byproducts) for nearly three decades (e.g., Brady et al., 1998; Clark et al., 2018; Daniels et al., 2014a; Daniels et al., 2016; Daniels et al., 2014b; Hornberger et al., 2004; Orndorff et al., 2015). These studies have shown that (1) rock type and extent of weathering influence TDS release, (2) shales and mudstones release more TDS than sandstones, and (3) unweathered rocks release more TDS than weathered materials. The specific conductance (SC) of column leachates typically starts near peak values, decreases during the first few pore volume leach cycles, and then stabilizes over the remaining leach cycles. For weathered overburden materials, peak leachate SC was often less than $500 \mu \mathrm{S} / \mathrm{cm}$, a proposed regulatory limit (Cormier et al., 2013a, b). Coal refuse produced during coal processing generated considerably higher peak SC and associated concentrations of TDS, acidity, and major and trace elements compared to overburden and interburden strata removed during mining operations (Cravotta and Brady, 2015; Daniels et al., 2014b; Orndorff et al., 2015). In one study (Daniels et al., 2014b), columns $\left(0.0012 \mathrm{~m}^{3}\right.$ rock) were upscaled to mesocosms $\left(1.5 \mathrm{~m}^{3}\right.$ rock) using the same rock samples but with larger size fragments than in the columns. SC declined significantly in both the columns and the mesocosms. Compared to the columns, the peak leachate SC was higher and the temporal decline of SC was not as steady in the mesocosms likely because the mesocosms were operated in a less controlled environment. In either case, the use of such laboratory and field kinetic tests can involve months to years to obtain results and generally requires kilograms of rock materials. 
A rapid batch extraction method that can be used to test small quantities of representative materials and that correlates well with field leachates would be of value to identify and manage rock types that release high TDS, and to characterize TDS from different energy extraction activities. For in-field determinations, "rapid" could refer to days if samples were shipped to a commercial laboratory, or hours if rock samples could be crushed and sieved, reacted with extractant solutions, and quantified for TDS release based on SC using a portable meter (discussed below). Because ABA parameters such as maximum potential acidity (MPA) and net neutralization potential (NNP) are used by coal companies to characterize overburden and are readily measured, their ability to be used to predict TDS release has been evaluated. Odenheimer et al. (2015) demonstrated that MPA and NNP may be useful to indicate general levels of low, moderate, and high TDS release; however, their semi-quantitative model was based on TDS computed from paste SC for a pulverized rock sample and did not consider upscaled or field-measured leachate characteristics. Modifying a method described by Barnhisel and Harrison (1976) and O'Shay et al. (1990), Orndorff et al. (2010) developed an alternative to the MPA method that used hydrogen peroxide $\left(30 \% \mathrm{H}_{2} \mathrm{O}_{2}\right)$ to oxidize sulfide minerals. They found that the peroxide potential acidity (PPA) was better than MPA as a predictor of TDS release from low-S rocks. However, the potential application of PPA to predict TDS release from a wide range of rock types was not evaluated.

The objectives of this research were to 1) develop and test a batch extraction method to predict TDS release from a range of rock types associated with energy extraction, 2) compare different batch extraction methods to results reported for column leaching tests and field-scale leachate, 3) evaluate those batch extraction methods to determine the most reliable method to quantify TDS release, and 4) identify tracers in leachate that may distinguish coal mining-derived TDS from other energy extraction sources.

\section{Materials and methods}

\subsection{Sample collection and preparation}

A total of 65 sedimentary rock and coal samples were obtained from multiple sources (Table 1). The samples represent important fossil fuelbearing strata in the Appalachian Basin, including bituminous coals and gas-producing shales. Eleven rock samples (3 weathered coal refuse, 8 overburden) were provided by Virginia Tech. Equivalent samples had been previously used in laboratory-scale, flow-through unsaturated column leaching experiments (Daniels et al., 2014b, 2016; Orndorff et al., 2015). Six rock samples ( 5 overburden, 1 pyrite) were provided by the U.S. Geological Survey.

(USGS). The five overburden samples had been previously characterized and used in laboratory-scale, flow-through column leaching experiments (Hammarstrom et al., 2009; Hornberger and Brady, 2009). The pyrite sample collected from the Bald Eagle Formation during construction of I-99 at the Skytop roadcut in Centre County, PA, along with paired water chemistry measurements had been previously described (Hammarstrom et al., 2005). Four overburden samples were provided by the University of Kentucky. Three of these sample materials had been used in field-scale lysimeter studies (mesocosms) (Agouridis et al., 2012; Sena et al., 2014) and all four had also been used in laboratory-scale, flow-through column leaching experiments (Daniels et al., 2016). Twenty unleached coal refuse samples from the roof and floor of the Pittsburgh coal, which is described by Brady et al. (1998), were collected from drill core materials stored in a repository maintained by the Pennsylvania Bureau of Topographic and Geologic Survey (PA TGS; Harrisburg, PA). Samples were collected from cores 8009, 8011, 8012, and 8013 that were drilled in Greene County, PA. One unleached Marcellus Shale sample was collected from drill core materials (Sullivan core at 8276 feet) stored by PA TGS. One unleached Utica/Point Pleasant Shale sample was collected from drill core materials stored in a repository maintained by the Ohio Geologic Survey (Columbus, OH). Eight samples of Utica/Point Pleasant Shale drill cuttings were provided by two gas development companies working in Pennsylvania. Finally, in March 2017, a total of 11 weathered coal refuse samples, 3 coal samples, and 4 coal refuse leachate samples were collected from two coal refuse disposal facilities (referred to as Mine A and Mine B) in western Pennsylvania.

\subsection{Rock type categorization}

Rock samples were sorted into six operational categories: coal (n 3 ), overburden (n 17), weathered coal refuse (n 14), unleached but oxidized coal refuse (n 20), gas-bearing shale (n 10), and pyrite (n

1) (Table 1). Coal refuse and overburden categories were differentiated based on the definitions in Pennsylvania Code Title 25 (Environmental protection), Chapter 87 (Surface mining coal), Section 87.1 (Definitions) (25 Pa. Code $\S$ 87.1) (Commonwealth of Pennsylvania, 2018a). Specifically, overburden is defined as "the strata or material overlying a coal deposit or between coal deposits in its natural state and shall mean material before or after its removal by surface mining". Coal refuse is defined as "any waste coal, rock, shale, slurry, culm, gob, boney, slate, clay and related materials, associated with or near a coal seam, which are either brought aboveground or otherwise removed from a coal mine in the process of mining coal or which are separated from coal during the cleaning or preparation operations". Shales closer in age and stratigraphic position to coal formations were included in coal refuse or overburden categories. The gas-bearing shale category included only the Utica/Point Pleasant Shale or Marcellus Shale samples. Pyrite included one sample from the Bald Eagle Formation at Skytop roadcut (Hammarstrom et al., 2005).

\subsection{Operational extractions}

Once received, rock samples were freeze-dried using a Labconco FreeZone 4.5 freeze dry system until constant weight was attained. Samples were crushed to $<4.75$-mm using a hydraulic press at $44.5 \mathrm{kN}$ and thereafter with a mortar and pestle until all particles were $<2$-mm in diameter. Samples were then pulverized using a Spex 8000 ball mill to produce particles $<0.5$-mm diameter (passed through No. 35 sieve).

Pulverized rock samples were sent to Geochemical Testing, a certified commercial laboratory in Somerset, PA, to conduct three operational extractions and analyze the $\mathrm{SC}, \mathrm{pH}$, and solute concentrations of various leachates. A fourth extraction was conducted at Pennsylvania State University to measure strontium isotopes $\left({ }^{87} \mathrm{Sr} /{ }^{86} \mathrm{Sr}\right)$. In Leach 1 (L1), rock samples were reacted with distilled deionized water (DI) under an ambient atmosphere. In Leach 2 (L2), rock samples were reacted with DI water under a $10 / 90 \% \mathrm{CO}_{2} / \mathrm{N}_{2}$ atmosphere. In Leach 3 (L3), rock samples were reacted with $30 \% \mathrm{H}_{2} \mathrm{O}_{2}(70 \%$ DI) under a 10 / $90 \% \mathrm{CO}_{2} / \mathrm{N}_{2}$ atmosphere. Aside from the differences noted above, the operational procedure for generating leachates followed the same steps. First, $10.00 \quad 0.05 \mathrm{~g}$ of pulverized rock $(<0.5-\mathrm{mm}$ sieve size $)$ was added to an Erlenmeyer 125-mL flask followed by $20 \mathrm{~mL}$ of the extractant solution. Addition of DI water in L1 and L2 was done rapidly in one aliquot. Addition of $\mathrm{H}_{2} \mathrm{O}_{2}$ in $\mathrm{L} 3$ was done slowly by adding $1 \mathrm{~mL}$ at a time to reduce bubbling caused by oxidation reactions. Flasks were then placed on a shaker table inside a controlled atmosphere apparatus. The lid of the controlled atmosphere apparatus was left open for L1 or sealed for L2 and L3. For the sealed conditions, $10 / 90 \% \mathrm{CO}_{2} / \mathrm{N}_{2}$ gas was constantly flushed through the apparatus. All extractions were shaken for $4 \mathrm{~h}$ at $50 \mathrm{rpm}$ and 20-22 C. After $4 \mathrm{~h}$, each sample was filtered through a $0.45-\mu \mathrm{m}$ cellulose acetate filter and $\mathrm{pH}$ and specific conductance (SC) of the filtrate were measured immediately (Oakton multiparameter PCTestr 35, calibrated with standards and buffers at 20-22 C). The filtrate was transferred to a $100-\mathrm{mL}$ volumetric flask and DI water was added to dilute the leachate to a final volume of $100 \mathrm{~mL}$ for analysis of elemental concentrations. Blank samples were prepared with 
DI water or $\mathrm{H}_{2} \mathrm{O}_{2}$ and followed all steps described above.

\subsection{Analytical methods}

A suite of analytes were measured for each of the three leachates (Supporting Information Tables SI-1 - SI-3). SC and pH were measured with electrodes submerged in the undiluted leachate. Major elements (Al, Ca, Fe, K, Mg, Mn, Na, P, S, Si) were measured after dilution to 100 $\mathrm{mL}$ on a Thermo Scientific iCAP 7400 inductively coupled plasma optical emission spectrometer (ICP-OES). Minor elements (As, Ba, Co, Cu, $\mathrm{Li}, \mathrm{Mo}, \mathrm{Ni}, \mathrm{Pb}, \mathrm{Se}, \mathrm{Sr}, \mathrm{Th}, \mathrm{Tl}, \mathrm{Ti}, \mathrm{U}, \mathrm{V}, \mathrm{Y}, \mathrm{Zn}, \mathrm{Zr}$ ) and rare-earth elements were measured on an Agilent 7900 inductively coupled plasma mass spectrometer (ICP-MS). Anions ( $\mathrm{Br}, \mathrm{Cl}, \mathrm{F}, \mathrm{NO}_{3}, \mathrm{SO}_{4}$ ) were measured on a Dionex DX-120 ion chromatograph (IC). Total inorganic carbon (TIC) was determined by infrared detection after persulfate oxidation (ASTM, 2017). ABA parameters were determined by standard methods (Sobek et al., 1978). Total sulfur (S) was analyzed by dry combustion, and maximum potential acidity (MPA) was calculated by multiplying total S (\%) by 31.25 to obtain $\mathrm{g} \mathrm{kg}{ }^{1} \mathrm{CaCO}_{3}$ equivalent. Neutralization potential (NP) was determined by reacting samples with $\mathrm{HCl}$ and titrating the effluent with $\mathrm{NaOH}$ using methods of Noll et al. (1988), without modification to account for siderite (Skousen et al., 1997). Net neutralization potential (NNP) was calculated by subtracting MPA from NP; negative NNP values imply a potentially acid-producing sample. The above analyses were conducted at Geochemical Testing, Somerset, PA.

Mineralogy of the rock samples was characterized by X-ray diffraction (XRD) using a PANalytical X'Pert 165 PRO MPD X-ray diffractometer equipped with a PIXcel detector operated in a 1D scanning mode with all channels active. Samples were subjected to $\mathrm{Cu} \mathrm{K}-\alpha$ radiation from 5 to $70(2 \theta)$ at $45 \mathrm{kV}$ and $40 \mathrm{~mA}$. Semi-quantitative analyses were performed using whole pattern fitting in Jade 2010 software from Materials Data Incorporated of Livermore, CA, in conjunction with reference files from the International Centre for Diffraction Data PDF4 database. Mineral detection limits were about $3 \%(\mathrm{~m} / \mathrm{m})$ and uncertainty in mineral fractions was $5 \%$.

\subsection{Speciation modeling methods}

The PHREEQC 3.0 aqueous speciation model (Parkhurst and Appelo, 2013) was used with input values for leachate data, corrected for dilution (100/volume leachate recovered), to estimate SC by methods reported by McCleskey et al. (2012) and Appelo et al. (2010) as described by Cravotta and Brady (2015). Input data to PHREEQC included the sample temperature, $\mathrm{pH}$, and the mass concentrations (mg/L) of TIC, $\mathrm{SO}_{4}, \mathrm{Cl}, \mathrm{F}, \mathrm{Br}, \mathrm{NO}_{3}-\mathrm{N}, \mathrm{P}, \mathrm{Si}, \mathrm{Ca}, \mathrm{Mg}, \mathrm{Na}, \mathrm{K}, \mathrm{Li}, \mathrm{Fe}, \mathrm{Mn}, \mathrm{Al}, \mathrm{Ba}, \mathrm{Sr}$, and $\mathrm{Zn}$ in the filtered leachates. Both methods calculated SC using the same speciated cations and anions $\left(\mathrm{H}, \mathrm{Li}, \mathrm{Na}, \mathrm{K}, \mathrm{Cs}, \mathrm{NH}_{4}, \mathrm{Mg}^{2}, \mathrm{Ca}^{2}\right.$, $\mathrm{Sr}^{2}, \mathrm{Ba}^{2}, \mathrm{~F}, \mathrm{Cl}, \mathrm{Br}, \mathrm{SO}_{4}^{2}, \mathrm{HCO}_{3}, \mathrm{CO}_{3}^{2}, \mathrm{NO}_{3}$, and $\mathrm{OH}$ ), trace metals $\left(\mathrm{Al}^{3}, \mathrm{Fe}^{2}, \mathrm{Fe}^{3}, \mathrm{Mn}^{2}\right.$, and $\left.\mathrm{Zn}^{2}\right)$, and charged ion pairs $\left(\mathrm{HSO}_{4}\right.$, $\mathrm{NaSO}_{4}, \mathrm{NaCO}_{3}$, and $\mathrm{KSO}_{4}$ ), however, the computations used to determine ionic conductivities were different. Briefly, the Appelo et al. (2010) method calculates the ionic conductivity of solute species using ion diffusion coefficients while the McCleskey at al. (2012) method calculates ionic molal conductivities using transport numbers. Both methods sum the ionic conductivity contributions to indicate the solution SC. Additional details on the SC computations are provided in the Supporting Information.

The concentration of total dissolved solids (TDS) was computed as the sum of the input concentrations of major dissolved constituents ( $\mathrm{Ca}$, $\mathrm{Mg}, \mathrm{Na}, \mathrm{K}, \mathrm{SO}_{4}, \mathrm{Cl}, \mathrm{CO}_{3}, \mathrm{NO}_{3}, \mathrm{SiO}_{2}$ ) (Fishman and Friedman, 1989) plus minor constituents ( $\mathrm{Sr}, \mathrm{Ba}, \mathrm{Fe}, \mathrm{Al}, \mathrm{Mn}, \mathrm{Br}$ ), assuming that $\mathrm{Fe}, \mathrm{Al}$, and $\mathrm{Mn}$ formed hydrous oxides (FeOOH, $\mathrm{AlOOH}, \mathrm{MnOOH}$ ) instead of anhydrous compounds. Cravotta and Brady (2015) showed that TDS values computed accordingly were comparable to the laboratory-measured residue on evaporation at $180 \mathrm{C}$ for mine effluent samples. Osmotic pressure (OP) was computed as the sum of molal concentrations of the same aqueous species used for SC calculations. The OP computation assumes that $1 \mathrm{~mol} / \mathrm{kg}$ of each ion exerts approximately $1 \mathrm{mOsm} / \mathrm{kg}$ osmotic pressure (Haynes, 2013). Cravotta and Brady (2015) showed that computed values of OP for mine effluent samples were comparable to standard laboratory-measured values of OP using freezing point depression (Kiyosawa, 2003).

\subsection{Data for upscaling comparisons}

Several of the rock samples characterized by operational batch extractions were previously used in laboratory-scale flow-through column experiments or obtained from field sites with paired water samples (Table 1). For upscaling batch extractions to column experiments, 16 overburden and 3 weathered coal refuse samples were compared using mass-normalized TDS. As TDS was not reported for column experiments (only SC), a SC-to-TDS conversion factor (CV TDS/SC mg TDS L ${ }^{1}$ / $\mu \mathrm{S} \mathrm{cm}{ }^{1}$ ) was calculated for each paired sample using the SC measured in L1 and the corresponding TDS value calculated using the input concentrations for PHREEQC (Supporting Information Tables SI-4). The cumulative TDS generated in the column experiment following approximately 14 or 40 discontinuous leaching events was calculated according to:

Cumulative column leached TDS $\frac{m g \text { TDS }}{L} \quad \frac{\sum_{n 1}^{i} S_{i} C_{i} \quad C V}{V_{\text {total }}}$

Eq 1

where, $S C_{i} \quad \mathrm{SC}$ measured from i-th leach event $\left(\mu \mathrm{S} \mathrm{cm}{ }^{1}\right) ; V_{i} \quad$ volume of each leach event (L); CV rock-specific SC-to-TDS conversion factor (mg TDS L ${ }^{1} / \mu \mathrm{S} \mathrm{cm}^{1}$ ); and $V_{\text {total }}$ total volume of leaches (L).

Comparisons between field sites and batch experiments were made based on SC, as this parameter was reported for all field samples. A total of 10 field sites were included (referred to as Mine A, Mine B, Mines P, KY1, KY2, KY3, KY9, LKFC, BCS3, Skytop), where SC measured from a select number of rock samples were paired with a varied number of SC values measured in the field. For Mine A, 42 records of SC and additional analytes from leachate drains were compared to five weathered coal refuse samples collected from Mine A. For Mine B, 41 records from leachate drains were compared to six weathered coal refuse samples collected from Mine B. For Mines A and B, records were obtained from a field sampling event in March 2017 and from Hydrologic Monitoring Reports (HMRs) submitted by the coal companies to the Pennsylvania Department of Environmental Protection. For Mines P, three records from influent discharges to three Pittsburgh coal mining/processing plants on active underground mines (Cravotta and Brady, 2015) were compared to 17 unleached coal refuse samples stratigraphically adjacent to the Pittsburgh coal horizon (TGS1-TGS17, Table 1). Field results for KY1-KY3 are summarized by Sena et al. (2014). For KY1, 199 records from field lysimeters built on top of a valley fill were compared to rock sample KY1 (unweathered overburden). For KY2, 110 records from field lysimeters installed on top of a valley fill were compared to rock sample KY2 (unweathered overburden). For KY3, 203 records from field lysimeters installed on top of a valley fill were compared to rock sample KY3 (unweathered overburden). For KY9, 18,064 records from a leachate drain at the toe of two valley fills were compared to rock sample KY9 (unweathered overburden). Three records of untreated effluent from coal processing plants (Cravotta and Brady, 2015) and 24 records from discharges from abandoned mines in the lower Kittanning coal horizon (Cravotta, 2008) were compared to rock sample LKFC (unweathered overburden). Six records from influent discharges from active mines (Cravotta and Brady, 2015) and 10 records from discharge samples from abandoned mines in the lower to upper Freeport coal horizons (Cravotta, 2008) were compared to rock sample BCS3 (unweathered overburden). Four records from drainage from the Skytop roadcut collected in May 2004 (Hammarstrom et al., 2005) were compared to rock sample SKYPA (pyrite). 

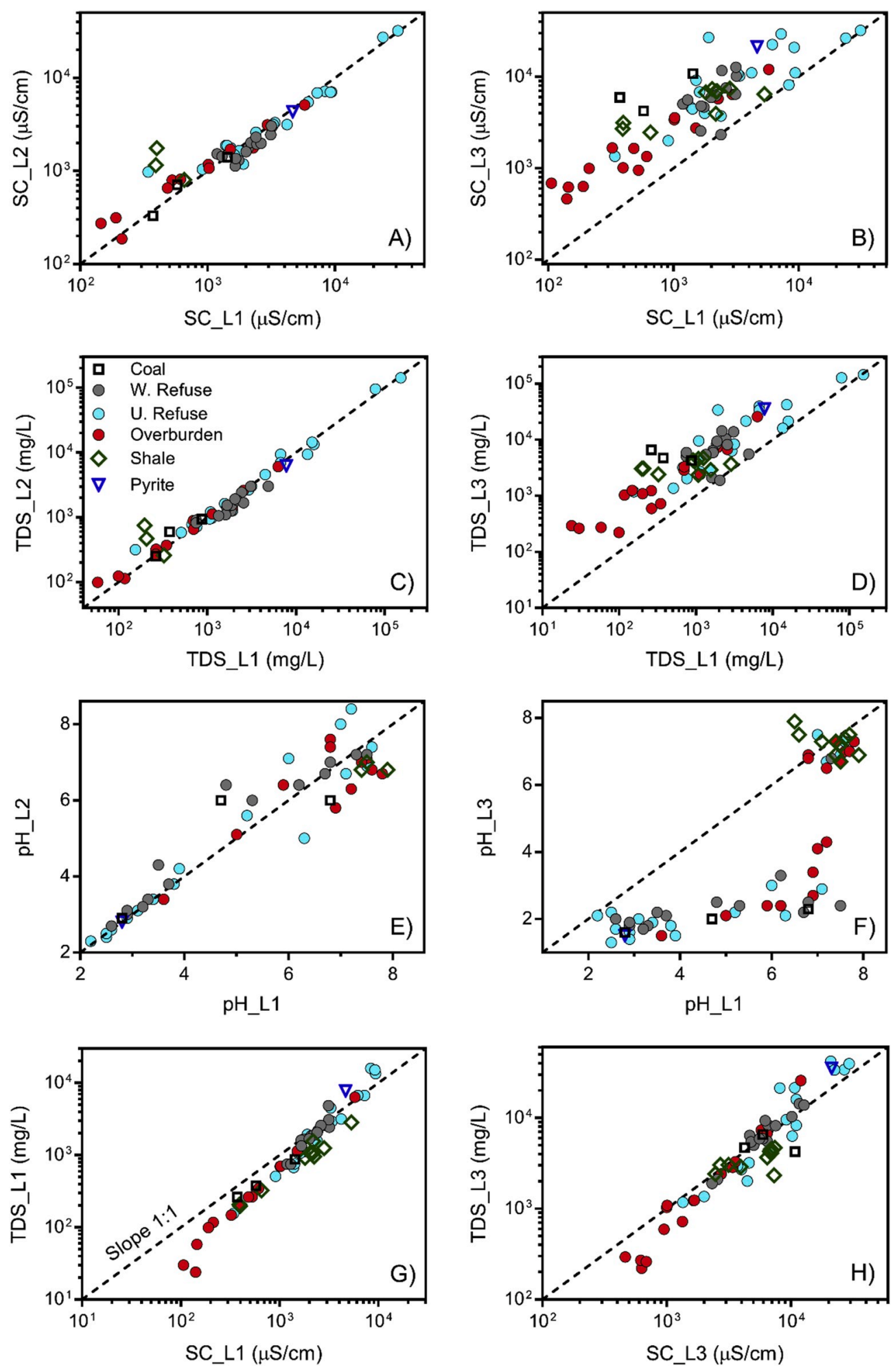

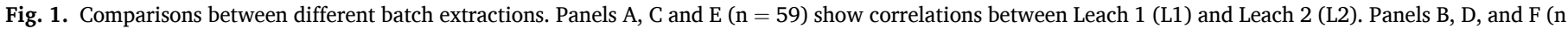
63) show correlations between L1 and Leach 3 (L3). Panels G and H (n 63) show correlations between SC and TDS in L1 and L3.

\subsection{Statistical methods}

Statistical differences between batch extractions (L1, L2, and L3) and upscaled results for selected parameters were evaluated using the Wilcoxon-signed rank test. Outliers were defined as values greater than the 75 th percentile plus 1.5 times the inter-quartile distance, or values smaller than the 25th percentile minus 1.5 times the inter-quartile distance. SC and TDS were compared via correlation (Pearson) analyses. Comparisons between TDS from leaches were compared with TDS from column experiments using Pearson correlation and by comparing the fit of our data $\left(R^{2}\right)$ with the line of equality y $x$. SC data from the field were compared with SC from batch extractions using an unpaired $t$-test. Linear regression equations were generated for each rock category and for the full data set. R software was used for all statistical analyses. 

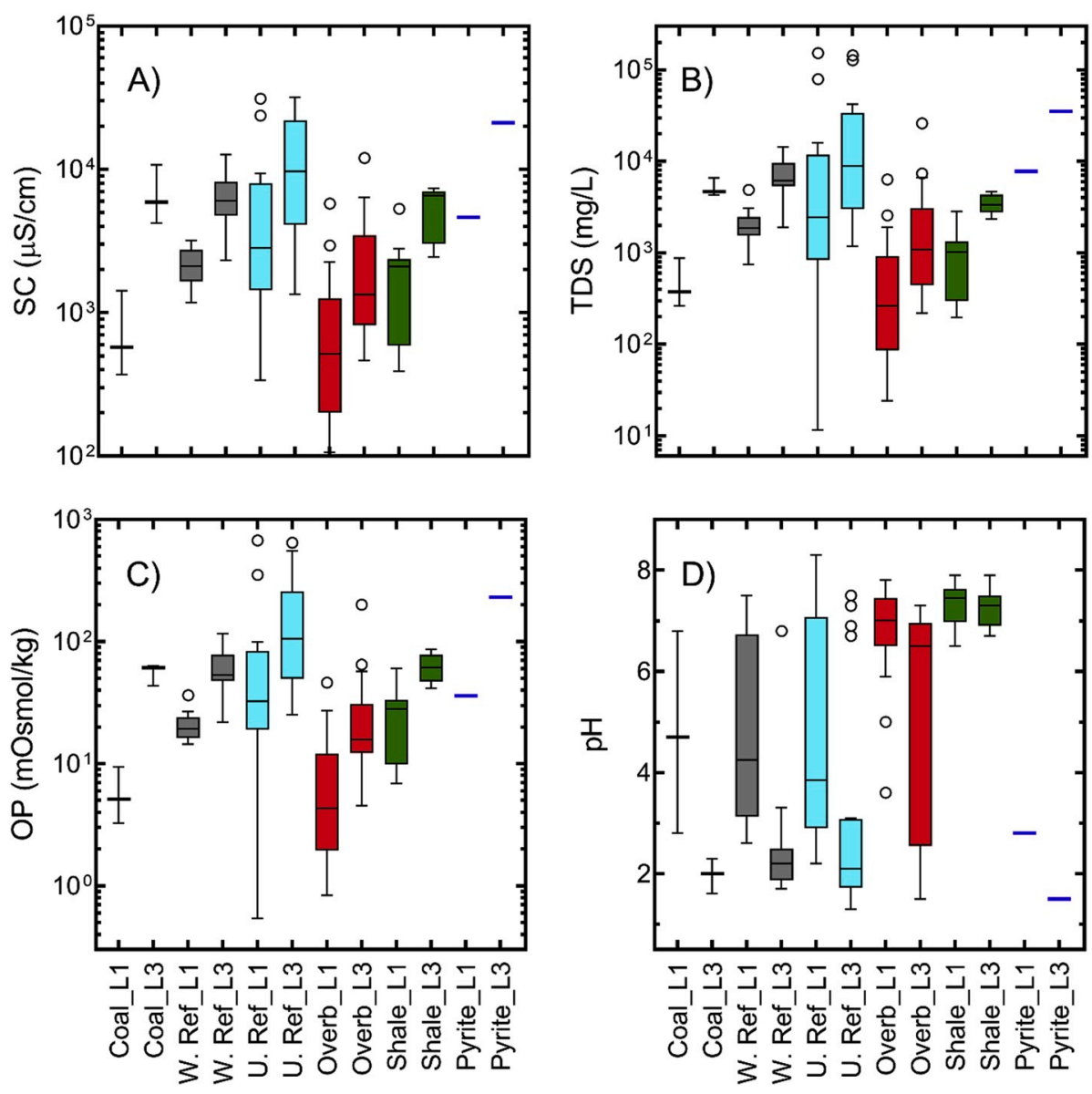

Fig. 2. Summary of chemistry for Leach 1 (L1) and Leach 3 (L3) for the six rock types. Coal (n 3); Weathered Coal Refuse W. Ref (n 14); Unleached Coal Refuse U. Ref (n 20); Overburden Overb (n 17); Shale (n 10); Pyrite (n 1). Box plots show median, $25 \%$ and $75 \%$ quartile ranges. Whiskers show the minimum and maximum values. Outliers (circles) defined as any point at a distance greater than 1.5 times the interquartile range measured from the 75 th to the 25 th percentile.

\section{Results and discussion}

\subsection{Comparison of operational extractions}

Three operational extractions were designed to have varying reactivity with sulfides, carbonates, silicates, sulfates, and salts. DI water alone (L1) was presumed to extract weakly held exchangeable ions, salts, hydrolysis products, and high-solubility minerals. The equilibration of the DI extractant with $10 \% \mathrm{CO}_{2}$ atmosphere (L2) was hypothesized to promote carbonate dissolution. Although the $\mathrm{pH}$ of the $\mathrm{L} 2$ extractant blank was less than that of L1, as described below, this level of $\mathrm{CO}_{2}$ did not create significant changes in the chemistries of leachates produced by $\mathrm{L} 1$ versus $\mathrm{L} 2$. In contrast, the $30 \% \mathrm{H}_{2} \mathrm{O}_{2}$ in $\mathrm{L} 3$ promoted sulfide oxidation, and the production of sulfuric acid promoted the dissolution of many other minerals. Relationships between SC, TDS, $\mathrm{pH}$, and TIC reflect the major reactions promoted by the extractant solutions. For example, for rocks with high sulfide and low carbonate contents (as determined by XRD), the increase in SC and TDS after the addition of $\mathrm{H}_{2} \mathrm{O}_{2}$ (i.e., $\mathrm{L} 1$ vs L3) was dominated by production of $\mathrm{SO}_{4}^{2}$ and $\mathrm{H}$. As another example, for rocks with low sulfide and high carbonate contents, the increase in SC and TDS after reaction with $\mathrm{CO}_{2}$ (i.e., $\mathrm{L} 1 \mathrm{vs} \mathrm{L2)}$ was controlled by release of $\mathrm{Ca}^{2}$ and $\mathrm{HCO}_{3}$.

Chemistry data for all rock samples are provided as spreadsheets in Supporting Information Tables SI-4 (leachates), SI-5 (blanks), and SI-6 (solids). For the blanks, the median (and range) of $\mathrm{pH}$ values were: L1, 6.0 (4.1-7.0, n 7); L2, 5.1 (4.4-6.3, n 5); and L3, 2.6 (1.8-4.5, n 7). The median measured SC values for the blanks were $13 \mu \mathrm{S} / \mathrm{cm}$ (5.0-85, n 7), $45 \mu \mathrm{S} / \mathrm{cm}(15-90, \mathrm{n} \quad$ 5), and $227 \mu \mathrm{S} / \mathrm{cm}(33-973, \mathrm{n}$ 7) in L1, L2, and L3, respectively. The median calculated TDS values for the blanks were $26 \mathrm{mg} / \mathrm{L}(16-223, \mathrm{n} \quad 7), 30 \mathrm{mg} / \mathrm{L}(14-34, \mathrm{n} \quad 5)$, and $138 \mathrm{mg} / \mathrm{L}(26-339, \mathrm{n} \quad$ 7) in L1, L2, and L3, respectively.
Operational extractions L1, L2, and L3 were compared based on $\mathrm{pH}$, TDS and SC results from all rock samples (Fig. 1). The D'Agostino \& Pearson normality test showed that the measured values for these parameters did not follow a normal distribution, therefore, comparisons between leachates were made using the Wilcoxon-signed rank test. This test showed that SC (measured and calculated), TDS, and $\mathrm{pH}$ values were significantly different (at 95\% confidence) in L3 compared with L1 and L2, and that differences between L1 and L2 were not significant (Supporting Information Tables SI-7). In general, L3 showed an increase in SC and TDS and a decrease in pH compared with L1 (Fig. 1B,D,F). As noted above, this was the result of the oxidation of sulfide minerals promoted by the use of $\mathrm{H}_{2} \mathrm{O}_{2}$ in $\mathrm{L} 3$. The decreased $\mathrm{pH}$ promoted the dissolution of carbonate minerals and release of $\mathrm{HCO}_{3}, \mathrm{Ca}^{2}$, and other ions into solution. Most of the samples showed a substantial increase in SC in L3 compared to L1 (Fig. 1B). However, six samples showed only a modest increase in SC (samples touching line of equality in Fig. 1B). These six samples contained high sulfate and low sulfide contents where the sulfate salts were quickly dissolved by water and the addition of $\mathrm{H}_{2} \mathrm{O}_{2}$ did not greatly enhance mineral dissolution. Of these six samples, four were unleached coal refuse (TGS 2A, TGS8, TGS10A, and TGD10B), one was weathered coal refuse (TNR2), and one was shale (SOH1). Consistent with statistical paired tests, results from L1 and L2 were similar (Fig. 1A,C,E). However, five samples showed an increase in SC in L2 compared to L1 (Fig. 1A). Of these five samples, two were gasproducing shales (SHM2, SHM3), one was unweathered coal refuse (TGS13), and two were sandstone overburden (VA16, WV5). The first three samples had abundant calcite and minor pyrite (Table 1). Although neither mineral was detected by XRD for VA16 or WV5 (Table 1), the two overburden samples had detectible NP and S (Table S3). In any case, the added $\mathrm{CO}_{2}$ in $\mathrm{L} 2$ appears to have enhanced carbonate dissolution. 

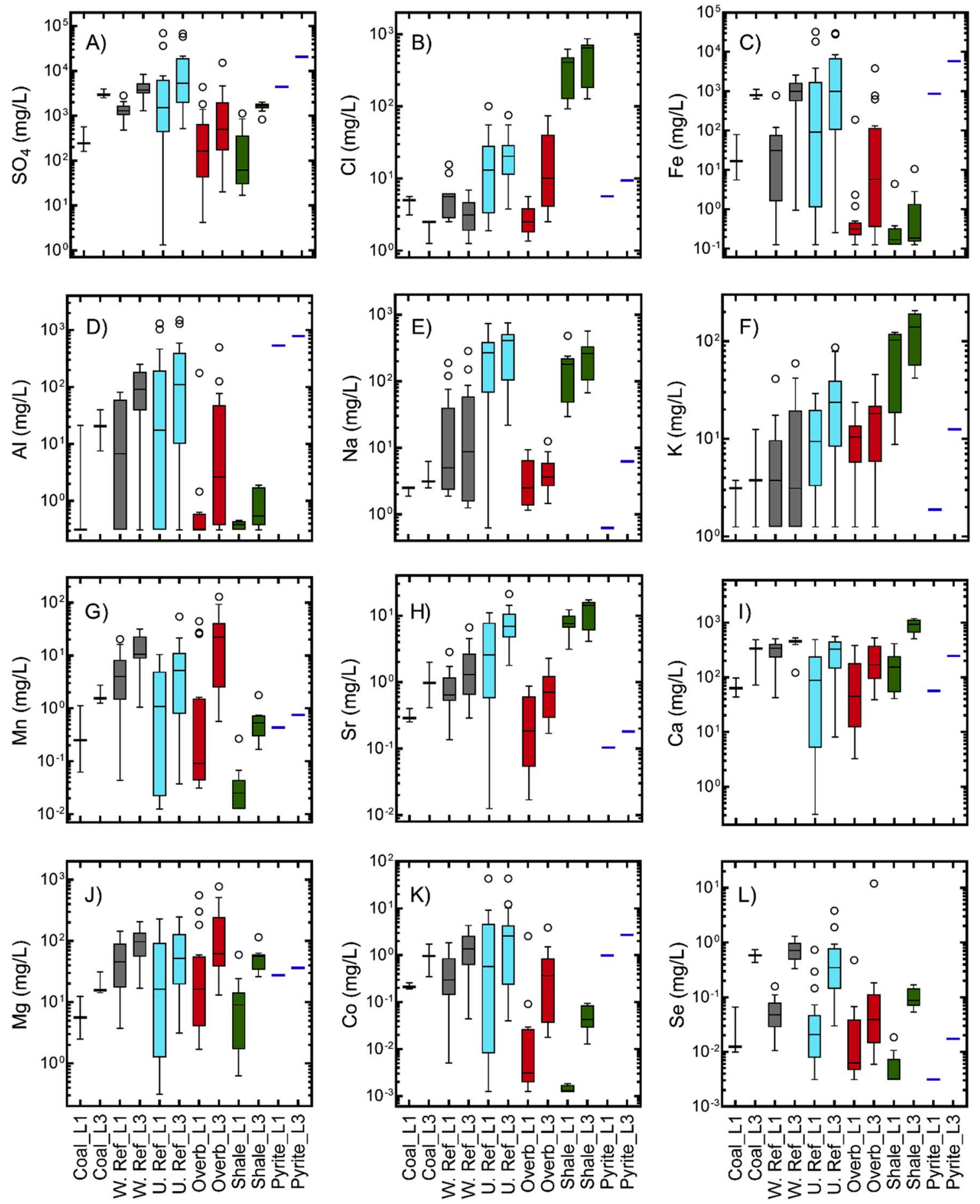

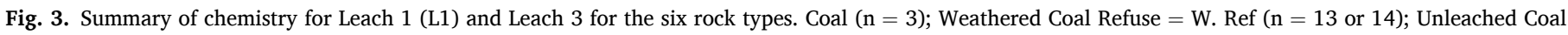

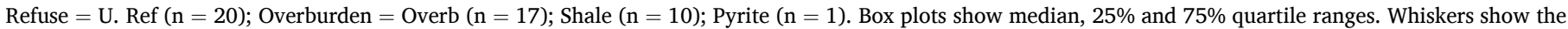

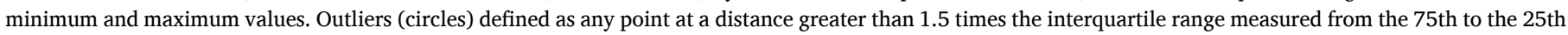

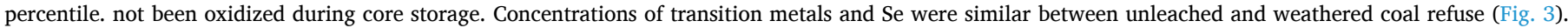

Most $\mathrm{pH}$ values for L3 were lower than those for L1 (Fig. 1F) because of enhanced sulfide oxidation by $\mathrm{H}_{2} \mathrm{O}_{2} \quad \mathrm{CO}_{2}$. However, many samples ( 23 of 65 ) with $\mathrm{pH}$ values ranging from 6.5 to 7.9 (samples clustered in upper right of Fig. 1F) exhibited little change in $\mathrm{pH}$ in L1 versus L3. These samples contained high carbonate and low sulfide contents, with corresponding positive values of NNP (Table 1 and Supporting Information Table S6) and produced enough alkalinity to neutralize the sulfuric acid produced. Of these 23 samples, 8 were shales, 6 were unleached coal refuse, 2 were weathered coal refuse, and 7 were overburden.

For the six rock types, median values for $\mathrm{pH}, \mathrm{SC}$, TDS, and OP were used to compare L1 and L3 (Fig. 2). In general, pyrite and unleached coal refuse produced the highest median values for SC and TDS while overburden produced the lowest median values. Median values for these parameters from weathered coal refuse, coal, and shale always ranked in intermediate positions, although the order switched depending on the analyte or extraction method. For instance, the order for TDS (mg/L) in L1 was pyrite $(7,770)>$ unleached coal refuse $(2,430)>$ weathered coal 


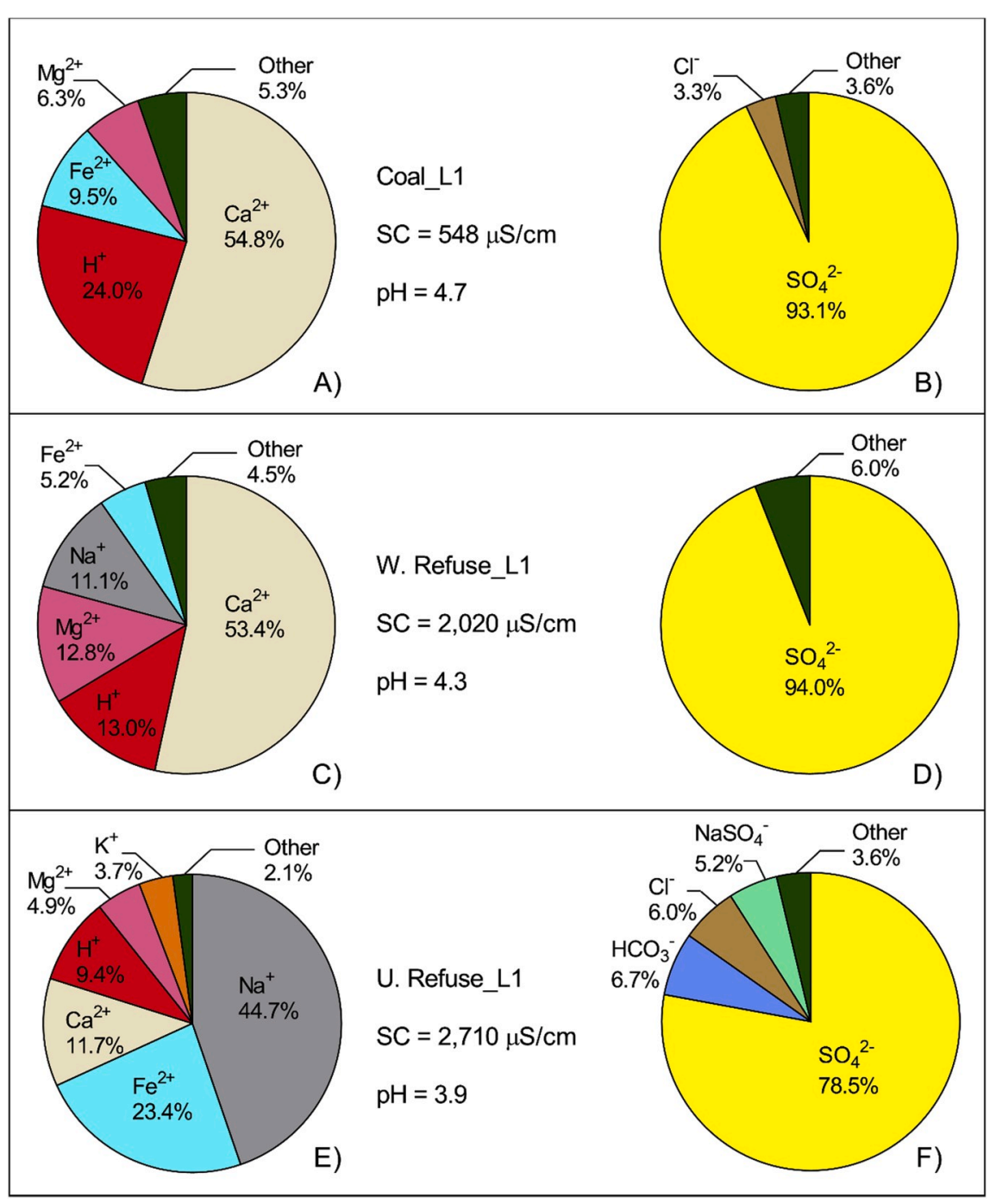

Fig. 4. Ionic contributions to specific conductance in Leach 1 (L1). Median specific conductance (SC), and ionic contributions calculated according to McCleskey et al. (2012). Median pH is shown for each rock category. Left panels show cationic contributions normalized to median SC for each rock category. Right panels show anionic contributions normalized to median SC for each rock category. Coal (n 3); Weathered Coal Refuse W. Refuse (n 14); Unleached Coal Refuse U. Refuse (n 20); Overburden (n 17); Shale (n 10); Pyrite (n 1). refuse $(1,870)>$ shale $(1,020)>\operatorname{coal}(375)>$ overburden $(262)$, while the order in L3 was pyrite $(35,200)>$ unleached coal refuse $(8,920)>$ weathered coal refuse $(6,160)>$ coal $(4,700)>$ shale $(3,360)>$ overburden $(1,080)$. Median values of TDS and SC in L3 were all higher than corresponding proposed regulatory reference levels, $500 \mathrm{mg} / \mathrm{L}$ and 300-500 $\mu \mathrm{S} / \mathrm{cm}$ (Cormier et al., 2013a,b; Pond et al., 2008; Timpano et al., 2010), respectively, for all rock types. Except for overburden, median values of $\mathrm{OP}$ in $\mathrm{L} 3$ were all higher than the regulatory reference level of $50 \mathrm{mOsmol} / \mathrm{kg}$ (Commonwealth of Pennsylvania, 2018b).

It is important to note that our results for TDS from Marcellus and Utica/Point Pleasant Shale are not consistent with values reported for waters produced from unconventional gas wells drilled into these formations. For instance, Tasker et al. (2019) reported median values of TDS of 240,000 mg/L for Utica/Point Pleasant Shale wells (n 24) and $225,000 \mathrm{mg} / \mathrm{L}$ for Marcellus Shale wells (n 60). Those values are nearly two orders of magnitude greater than the median TDS obtained for gas-bearing shales with our most aggressive extractant (TDS_L3 $3360 \mathrm{mg} / \mathrm{L}$ ). Produced water from hydraulically fractured shale gas wells could encounter extensive small fracture networks equivalent to exceptionally low water-to-rock ratios or could interact with brines that were not within (or preserved) in our samples. This is consistent with other studies that have shown TDS values from batch extractions of Marcellus Shale are much lower than corresponding field-produced waters (Chapman et al., 2012; Phan et al., 2015; Rowan et al., 2011;
Stewart et al., 2015; Tasker et al., 2016; Warner et al., 2012).

\subsection{Leachate composition}

The median concentrations of dissolved metals, metalloids, and anions varied based on rock type, weathering extent, and final $\mathrm{pH}$ of the extract (Fig. 3). Based on sample mineralogy and leachate composition, the principal mechanisms for TDS generation are oxidation of sulfide minerals (with production of $\mathrm{H}_{2} \mathrm{SO}_{4}$ ) that promotes increased solubility of metals (e.g., $\mathrm{Fe}, \mathrm{Al}, \mathrm{Mn}$ ), dissolution and hydrolysis of carbonate and silicate minerals to neutralize acidity, and dissolution of high-solubility minerals such as sulfates and salts. Because of its high organic carbon content, coal contained relatively low concentrations of metals. Based on XRD (Table 1), coal samples contained quartz, calcite, clays, and pyrite. Concentrations of $\mathrm{Si}, \mathrm{Ca}, \mathrm{Al}, \mathrm{Fe}$, and $\mathrm{SO}_{4}$ in the coal leachates are consistent with this mineral assemblage.

Weathered coal refuse had been exposed to shallow subsurface weathering for years, while rock cores classified in this study as unleached coal refuse had been exposed to humid air only while archived in core boxes. These differences in weathering extent led to distinct differences in leachate chemistry. Unleached coal refuse released higher alkali metals, notably $\mathrm{Na}$, and higher $\mathrm{Cl}$ compared to weathered coal refuse (Fig. 3), reflecting that salts had been preserved in storage. Plots of $\mathrm{Cl}$ versus Na molar concentrations in both L1 and L3 


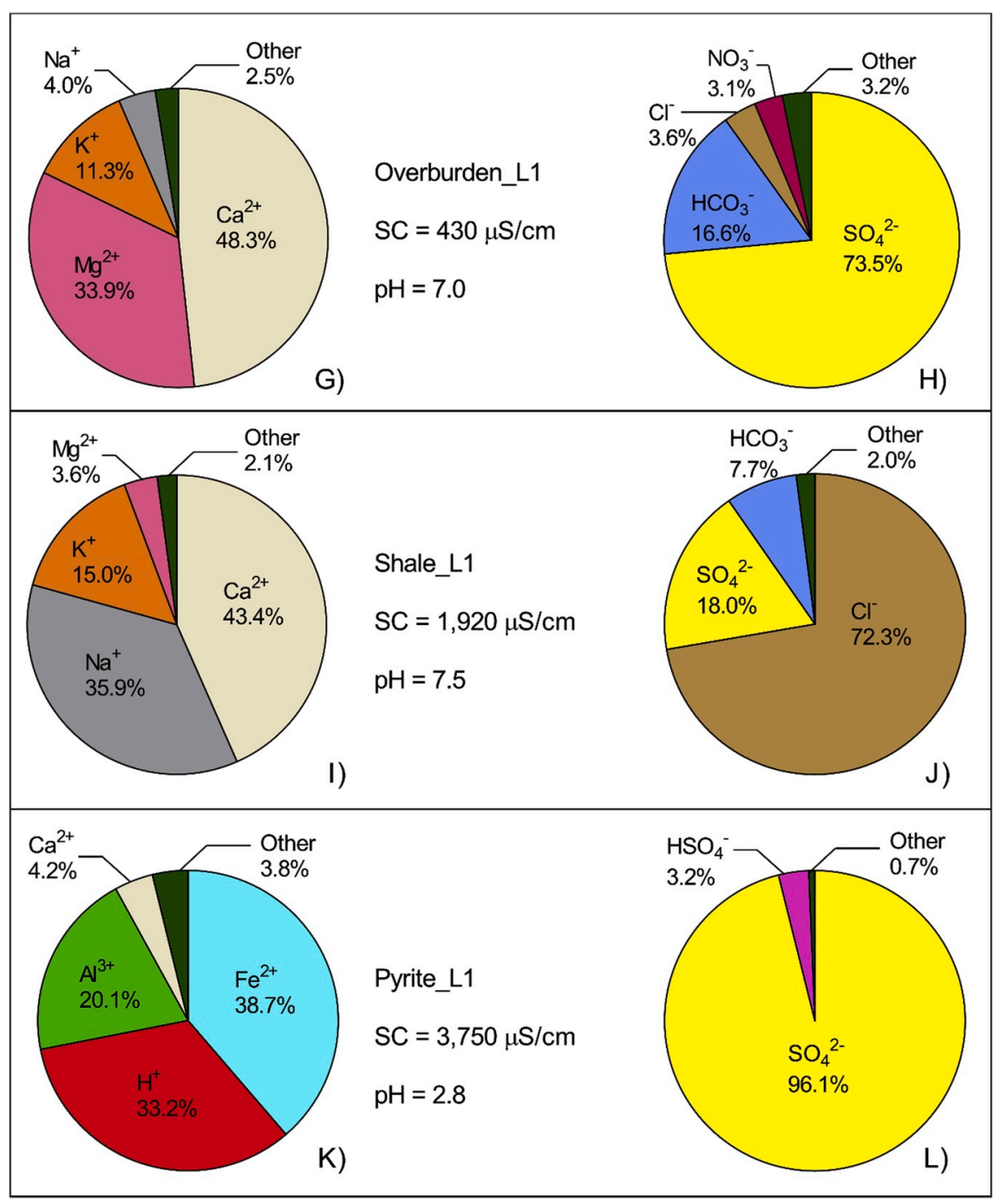

Fig. 4. (continued).

showed that only the shale samples consistently plotted along the 1:1 line of equality supporting the assumption of $\mathrm{NaCl}$ dissolution (Supporting Information Fig. SI-1). Na was also likely sourced from exchange reactions and silicate neutralization. Unleached coal refuse also released higher $\mathrm{SO}_{4}$, notably in $\mathrm{L} 3$, compared to weathered coal refuse, reflecting that some sulfides had not been oxidized during core storage. Concentrations of transition metals and Se were similar between unleached and weathered coal refuse (Fig. 3).

Differences in mineral composition (Table 1) of overburden, shale, and pyrite help explain differences in leachate chemistry. In L3, overburden samples released low alkali metals and chloride, reflecting low entrained salt content, and low $\mathrm{SO}_{4}$ reflecting low sulfide content. Gasbearing shale samples released high alkali metals and the highest amounts of $\mathrm{Cl}$ and $\mathrm{Br}$, reflecting relatively high salt content, low $\mathrm{SO}_{4}$ reflecting low sulfide content, and high alkaline earth metals, notably $\mathrm{Sr}$ and $\mathrm{Ba}$, reflecting high carbonate content. The sole pyrite sample released the highest amounts of $\mathrm{Fe}, \mathrm{SO}_{4}, \mathrm{Al}, \mathrm{Pb}, \mathrm{Zn}$, and As reflecting high sulfide content.

\subsection{Contribution of ionic species to specific conductance}

The relative contributions of ionic species to the SC were calculated for all rock types in L1 and L3 using the method of McCleskey et al. (2012). For L1, the major cationic contributions to SC were $\mathrm{Ca}^{2}>\mathrm{Na}$ $>\mathrm{Mg}^{2}>\mathrm{Fe}^{2}>\mathrm{H}>\mathrm{K}$, and major anionic contributions to SC were
$\mathrm{SO}_{4}^{2}>\mathrm{Cl}>\mathrm{HCO}_{3}$ (Figs. 4 and 5). However, the rank of ion contributions to SC differed slightly depending on rock type. For instance, $\mathrm{Ca}^{2}$ was the dominant cation in coal, weathered coal refuse, overburden, and gas-bearing shale, but $\mathrm{Na}$ was the dominant cation in unleached coal refuse and $\mathrm{Fe}^{2}$ was the dominant cation in pyrite. On the other hand, the anionic contributions to $\mathrm{SC}$ were dominated by $\mathrm{SO}_{4}^{2}$ for all rock types except for gas-bearing shale, where $\mathrm{Cl}$ was most abundant. The high contribution of $\mathrm{Cl}, \mathrm{Na}$, and $\mathrm{Ca}^{2}$ to SC in gas-bearing shales (Fig. 4I and J) provide evidence for salt dissolution. The general contribution of principal cations and anions to SC in L1 were consistent with the mechanisms of TDS generation discussed above.

With the addition of $\mathrm{H}_{2} \mathrm{O}_{2}$ to $\mathrm{L} 3$, sulfide oxidation and the consequent release of sulfuric acid became an important mechanism for ion mobilization by mineral dissolution. While the major ions that contribute to SC in L3 were similar to those in L1, the contribution of $\mathrm{H}$ increased markedly in L3 (Fig. 5). The major cationic contributions to SC in $\mathrm{L} 3$ were $\mathrm{H}>\mathrm{Ca}^{2}>\mathrm{Fe}^{2}>\mathrm{Na}>\mathrm{Mg}^{2}>\mathrm{K}$. Anionic contributions to $\mathrm{SC}$ in $\mathrm{L} 3$ were dominated by $\mathrm{SO}_{4}^{2}>\mathrm{HSO}_{4}>\mathrm{Cl}>\mathrm{HCO}_{3}$. $\mathrm{Na}$ was an important contributor to $\mathrm{SC}$ from unleached coal refuse and gas-bearing shale. The increased release of $\mathrm{Na}$ from gas-bearing shale with $\mathrm{L} 3$ compared to L1 is consistent with silicate mineral decomposition combined with salt dissolution. $\mathrm{Cl}$ was an important contributor to SC of L3 only from gas-bearing shale, where the $\mathrm{SO}_{4}^{2}$ release was greater than $\mathrm{Cl} . \mathrm{Mg}^{2}$ and $\mathrm{HCO}_{3}$ were important contributors to SC only from overburden. Although $\mathrm{pH}$ of $\mathrm{L} 3$ remained near-neutral for the gas- 


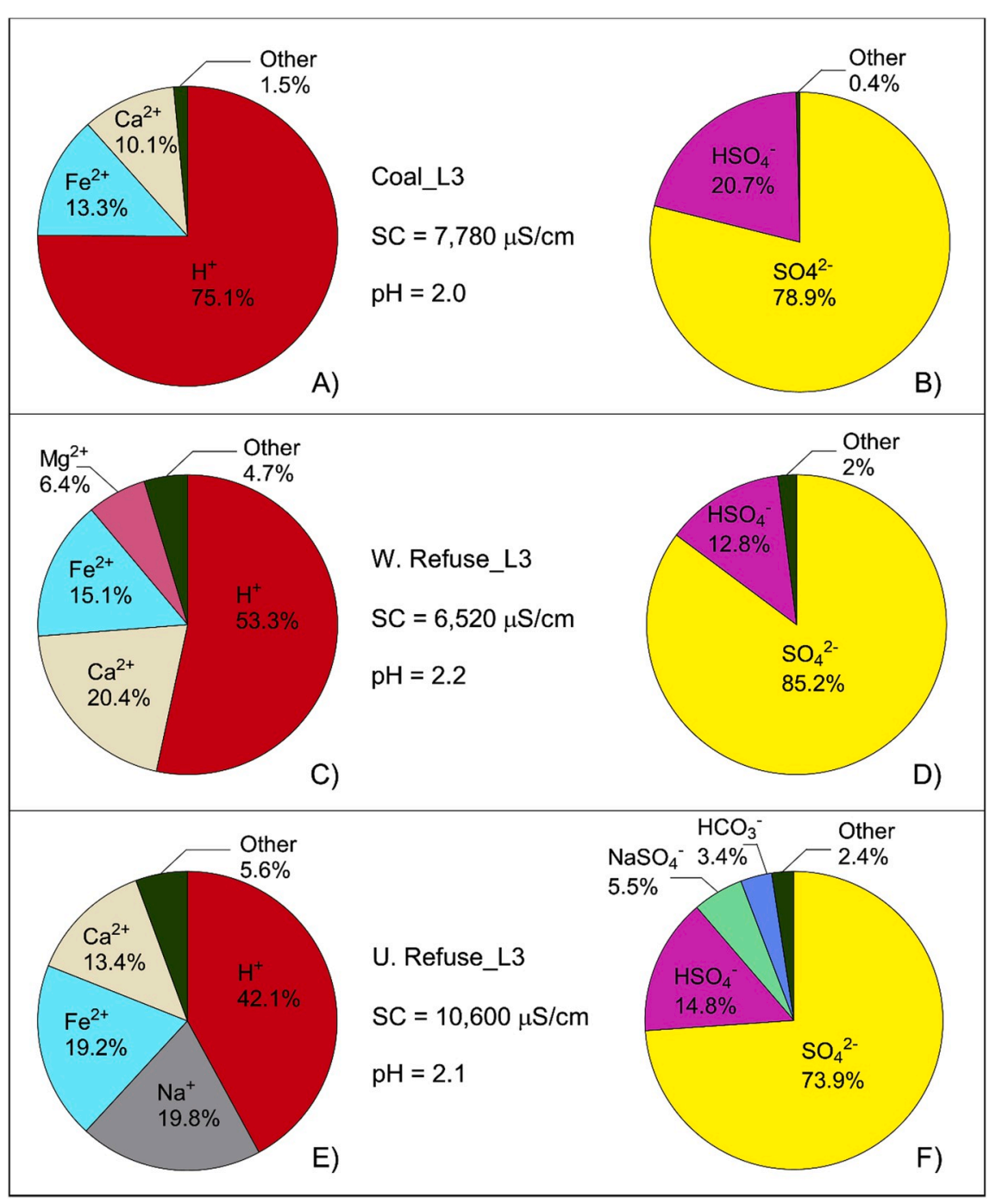

Fig. 5. Ionic contributions to specific conductance in Leach 3 (L3). Median specific conductance (SC), and ionic contributions calculated according to McCleskey et al. (2012). Median pH is shown for each rock category. Left panels show cationic contributions normalized to median SC for each rock category. Right panels show anionic contributions normalized to median SC for each rock category. Coal (n 3); Weathered Coal Refuse W. Refuse (n 14); Unleached Coal Refuse U. Refuse (n 20); Overburden (n 17); Shale (n 10); Pyrite (n 1). bearing shale and overburden, the increased release of $\mathrm{SO}_{4}^{2}, \mathrm{Ca}^{2}$, and $\mathrm{Na}$ with L3 compared to L1 demonstrates the importance of mineral decomposition in conjunction with pyrite oxidation, acidification, and neutralization.

\subsection{Upscaling from lab to field}

An important part of this study was to test the capability of the proposed rapid batch extractions on 10-g samples for predicting TDS release from coal refuse and overburden of larger size and at longer time scales. Available information from previous column studies and water quality data from 10 field sites were compared with our batch extractions. Seventeen overburden samples and three weathered coal refuse samples (Table 1) were previously analyzed in column studies (Agouridis et al., 2012; Daniels et al., 2009, 2014b, 2016; Hornberger and Brady, 2009; Odenheimer et al., 2015; Sena et al., 2014). In general, all column studies maintained unsaturated conditions with simulated rainfall ( $\mathrm{pH}$ 4.6) leaching events. The number and frequency of leach events, the rainfall volume, and the rock mass in the columns varied between experiments conducted by Daniels et al. (2016) versus Hornberger and Brady (2009). Daniels et al. (2016) constructed columns with $1200 \mathrm{~cm}^{3}(\sim 1800 \mathrm{~g})$ of rock and applied $125 \mathrm{~mL}$ of synthetic rain water twice a week for a total of 40 leach events. Hornberger and Brady (2009) constructed columns with 1300 to $2100 \mathrm{~g}$ of rock and applied 190-650
$\mathrm{mL}$ of synthetic rain water once a week for a total of 14 leach events. As described below, the overall water volume (sum of individual leaches) to rock mass ratio strongly controls leachate chemistry. As these two groups of researchers ultimately used similar water-to-rock ratios in their column studies, results from all studies are comparable when normalized to rock mass. In general, SC in the column leachates started at the highest values, declined in an exponential manner, and then approached an asymptotic minimum. Comparisons with batch experiments were made based on cumulative TDS calculated from the column experiments. Column leachate data were compiled as SC and then converted to TDS, based on rock-specific correlations derived from L1, using Eq (1). Based on this approach, we found that TDS from batch extraction L1 and cumulative TDS calculated from column experiments were well correlated (Fig. 6). These batch and column methods likely produced similar amounts of cumulative TDS because the water-to-rock ratios used in all experiments were of similar order of magnitude (2 mL-to-1 $\mathrm{g}$ in batch experiments versus $2.5 \mathrm{~mL}$-to- $1 \mathrm{~g}$ to $3.2 \mathrm{~mL}$-to- $1 \mathrm{~g}$ in column experiments), and the smaller particle size used in the batch extractions ( $0.5-\mathrm{mm}$ for batch experiments versus 2-mm to $1.25-\mathrm{cm}$ for column experiments) may promote more rapid release of TDS. However, overburden samples that produced the lowest amounts of TDS in L1 produced more cumulative TDS via column leaching (lower left of Fig. 6A).

TDS from batch extraction L3 tended to overpredict cumulative TDS 


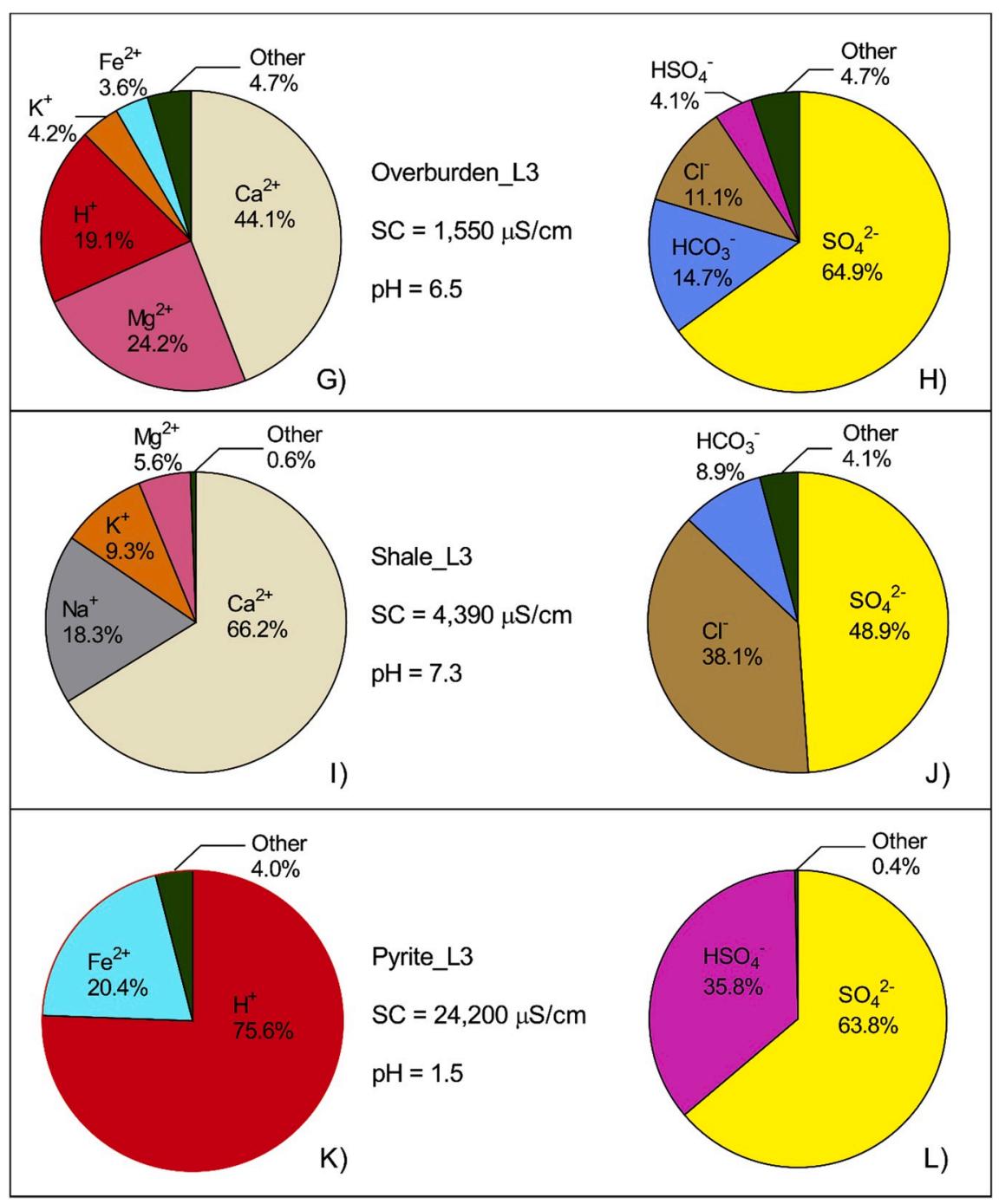

Fig. 5. (continued).
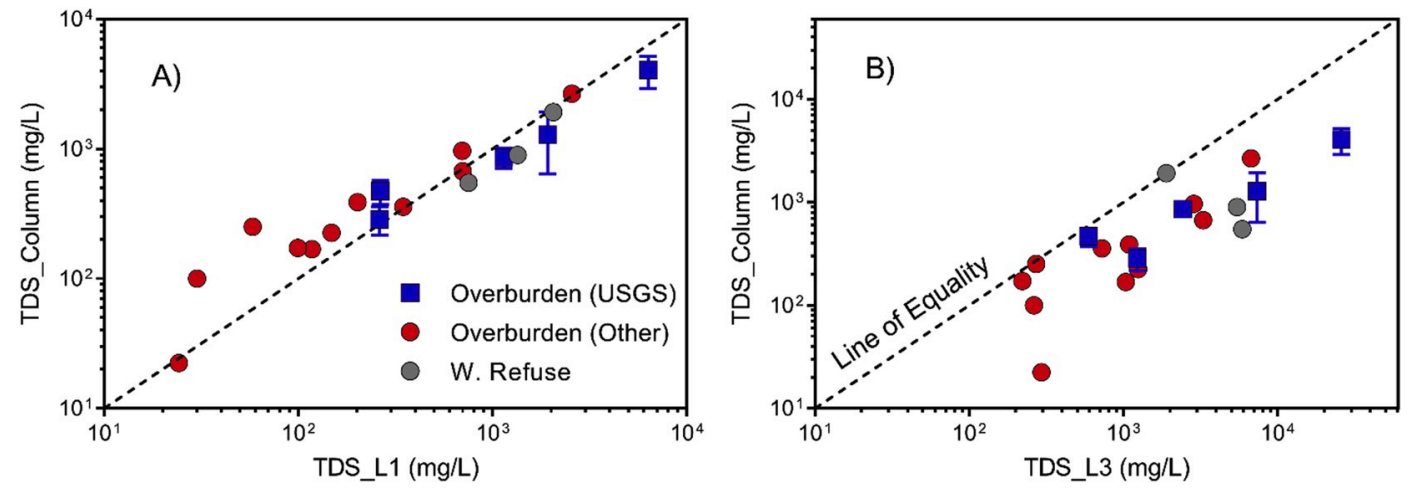

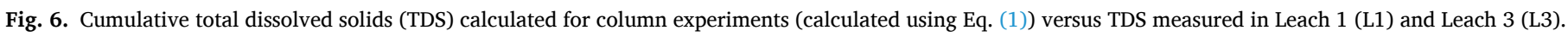

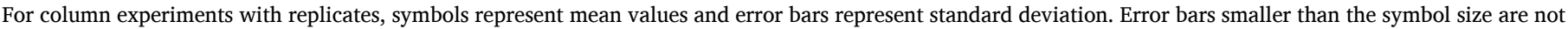
shown. Weathered coal refuse W. Refuse (n $\quad 3$ ). Overburden samples donated by USGS Overburden (USGS) (n 5), overburden samples from other sources Overburden (Other) (n 11).

calculated from the column experiments (Fig. 6B; Supporting Information Tables SI-8). These results suggest that even multiple column leaching events cannot achieve the extractive strength of $\mathrm{H}_{2} \mathrm{O}_{2} \quad \mathrm{CO}_{2}$ used in batch extraction L3. Furthermore, these results suggest that multiple discontinuous rainfall leaching events do not substantially increase the extractive strength of synthetic rain (or physical access to additional reactive sites), and that the cumulative water-to-rock ratio exerts greater control on leachate chemistry for water extractions.

In contrast to the column experiments, field SC was better correlated to SC from batch extraction L3 versus L1 (Fig. 7; Supporting Information Tables SI-9). Field data and batch extractions were compared for 9 of the 10 field sites using an unpaired $t$-test (not enough data were 

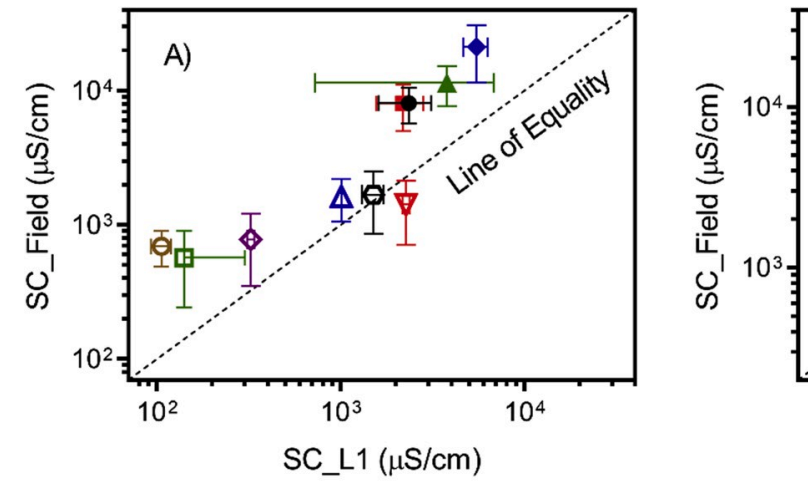

B)

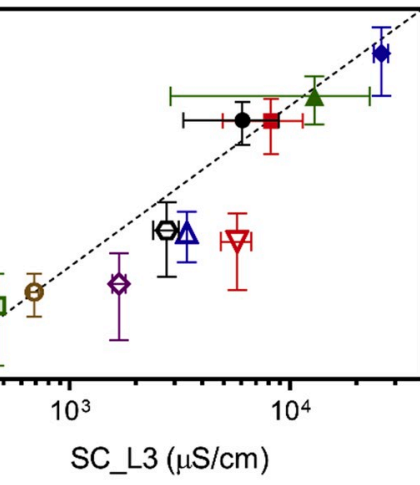

\begin{tabular}{|llllllllll|}
\hline$\bullet$ & Mine A & $\bullet$ & Skytop & 0 & BCS3 & $\square$ & KY1 & $\diamond$ & KY3 \\
$\square$ & Mine B & $\Delta$ & Mines P & $\nabla$ & LKFC & $\circ$ & KY2 & $\Delta$ & KY9 \\
\hline
\end{tabular}

Fig. 7. Relationships between specific conductance (SC) measured in the field and in A) Leach 1 (L1) and B) Leach 3 (L3). Symbols represent mean values and error bars represent standard deviation. For SC measured in the field: Mine A ( $\mathrm{n} \mathrm{42);} \mathrm{Mine}$ B (n 41); Mines P ( $\quad$ 3); KY1 (n 199), KY2 (n 110), KY3 (n 206), KY9 (n 18,064); LKFC (n 25); BSC3 (n 16); Skytop (n 4). For SC measured in L1: Mine A (n 5); Mine B ( $\mathrm{n}$ 6); Mines P ( $\mathrm{n}$ 17); KY1 (n 3); KY2 (n 3); KY3 (n 3); KY9 (n 1); LKFC (n 3); BSC3 (n 3); Skytop (n 8). For SC measured in L3: Mine A (n 5); Mine B ( $\quad$ 6); Mines P ( $\quad$ 17); KY1 ( 3); KY2 (n 3); KY3 (n 3); KY9 (n 1); LKFC (n 2); BSC3 (n 2); Skytop (n 14).
Table 2

Correlations between TDS and ABA parameters. MPA Maximum Potential Acidity; SC Specific conductance; $r$ correlation coefficient.

\begin{tabular}{|c|c|c|c|c|c|}
\hline \multirow[t]{2}{*}{ Rock Type } & \multirow[t]{2}{*}{$\mathrm{N}$} & \multicolumn{2}{|c|}{ Linear regression } & \multicolumn{2}{|c|}{ Pearson Correlation } \\
\hline & & SC_L3 & $\mathrm{m} * \mathrm{MPA}$ & $\mathrm{R}$ & $\mathrm{P}$ \\
\hline \multicolumn{6}{|l|}{ Leach 3} \\
\hline Coal & 3 & SC_L3 & 89.6*MPA 11700 & 0.563 & 0.619 \\
\hline W. Refuse & 14 & SC_L3 & $7.74 * \mathrm{MPA} \quad 7280$ & 0.187 & 0.523 \\
\hline U. Refuse & 17 & SC_L3 & 75.6*MPA 4010 & 0.835 & $<0.0001$ \\
\hline Overburden & 13 & SC_L3 & $86.5 *$ MPA 1220 & 0.921 & $<0.0001$ \\
\hline Shale & 10 & SC_L3 & $74.0 * \mathrm{MPA} \quad 2350$ & 0.387 & 0.269 \\
\hline All data & 58 & SC_L3 & $57.9 * \mathrm{MPA} \quad 3350$ & 0.663 & $<0.0001$ \\
\hline \multirow[t]{2}{*}{ Rock Type } & $\mathbf{N}$ & \multicolumn{2}{|c|}{ Linear regression } & \multicolumn{2}{|c|}{ Pearson Correlation } \\
\hline & & TDS_L3 & $\mathbf{m} *$ MPA & $\mathbf{R}$ & $\mathbf{P}$ \\
\hline Coal & 3 & TDS_L3 & $56.8 * \mathrm{MPA} \quad 2170$ & 0.989 & 0.0949 \\
\hline W. Refuse & 14 & TDS_L3 & $8.41 * \mathrm{MPA} \quad 8090$ & 0.167 & 0.568 \\
\hline U. Refuse & 17 & TDS_L3 & $130 * \mathrm{MPA}-2770$ & 0.858 & $<0.0001$ \\
\hline Overburden & 13 & TDS_L3 & $196 * \mathrm{MPA}-267$ & 0.985 & $<0.0001$ \\
\hline Shale & 10 & TDS_L3 & 26.1 *MPA 2420 & 0.326 & 0.358 \\
\hline All data & 58 & TDS_L3 & $100 * \mathrm{MPA}-1880$ & 0.692 & $<0.0001$ \\
\hline
\end{tabular}

available to test the other three sites). Seven of the nine sites showed no statistical differences between field SC and L3 SC. We note that field SC values from rock disposal facilities (that is, excess spoil fills pursuant to SMCRA) change over time, and that the 'age' of the rock/leachate could not be controlled in this study. However, we chose to analyze all these sites together because they represent the largest, most analytically consistent data set available for addressing our research objectives. In contrast, five of the nine sites showed significant statistical differences between field SC and L1 SC, where SC results from L1 underestimated the field SC.

Collectively these upscaling comparisons suggest that weathering in the field is influenced by acid-formation and neutralization reactions that produce greater solute concentrations than simple dissolution of soluble salts and exchangeable ions by water alone. Column leaching experiments produce high SC in the first leaches, but values decline rather quickly. Scaling up from column experiments to field sites is challenging for a number of reasons. One obvious issue is that coal refuse disposal fills often contain millions of cubic meters of rock such that the rock-to-water ratio is dramatically greater in the field as compared to tens of pore volumes eluted through laboratory columns. Unlike column experiments, water percolating through rocks stored in disposal fills may encounter multiple and much longer flow paths such that the water encounters more 'fresh' reactive material. Water may migrate through these rocks much slower and encounter many more wetting-and-drying cycles as compared to column experiments such that the field leachates oxidize more sulfides, generate a lower $\mathrm{pH}$, and solubilize more metals. Rocks in disposal fills may also disaggregate over long periods of time, effectively increasing the rock-to-water ratio.

\subsection{Correlations between $S C$ and $A B A$ parameters}

Acid-base accounting (ABA) parameters are used to identify and segregate rocks with high acid generation potential (or blend with rocks with high alkalinity). The use of ABA parameters to identify TDS release potential would be cost-effective for coal mine operators, provided that the TDS predictions based on ABA were accurate. Of all the correlations between ABA parameters and analytes measured in L1 and L3 extracts, maximum potential acidity (MPA) displayed the most promising correlations with SC from L3 (Table 2). It was anticipated that MPA NP might better predict TDS release, but this did not produce an improved relationship. While MPA is certainly correlated with TDS release, correlation coefficients were not high for all rock types and notably low for weathered coal refuse, plus different linear regression coefficients (slope and intercept) were indicated for different rock types (Supporting Information Fig. SI-2). Therefore, an additional measure such as batch extraction L3 to measure TDS release potential would still be needed.

Correlations between XRD-based mineral contents, ABA parameters, and selected leachate chemistry parameters (Supporting Information Tables SI-11) confirmed that samples containing sulfide and sulfate minerals had higher total S, and samples containing calcite and dolomite had higher NP. The strongest predictor of leachate salinity (SC, TDS, or $\mathrm{OP}$ ) was the total $\mathrm{S}$ content and the presence of sulfur minerals. These correlations support the hypothesis that L1 liberates sulfur and iron mainly from iron sulfate minerals formed by prior oxidation of pyrite. Identification of specific iron sulfide or sulfate minerals does not seem to be particularly informative for predicting water chemistry; however, oxidation of the sulfides is required to release the potential acidity. Consequently, the significance of correlations between ABA parameters and salinity parameters increases from L1 to L3 (which seems to mobilize greater $\mathrm{Ca}$ from carbonates in conjunction with sulfide oxidation).

\subsection{Correlations among $S C, p H$, and element concentrations}

Concentrations of major and minor elements and various measures of ionic strength were positively correlated with the measured SC (Fig. SI3) and inversely correlated with the pH (Fig. SI-4). The apparent SC and $\mathrm{pH}$ distributions and correlations reflect the weathering contributions of different rock types (Fig. SI-5), with increased SC and decreased $\mathrm{pH}$ resulting from more extensive weathering of rock samples from coal- 

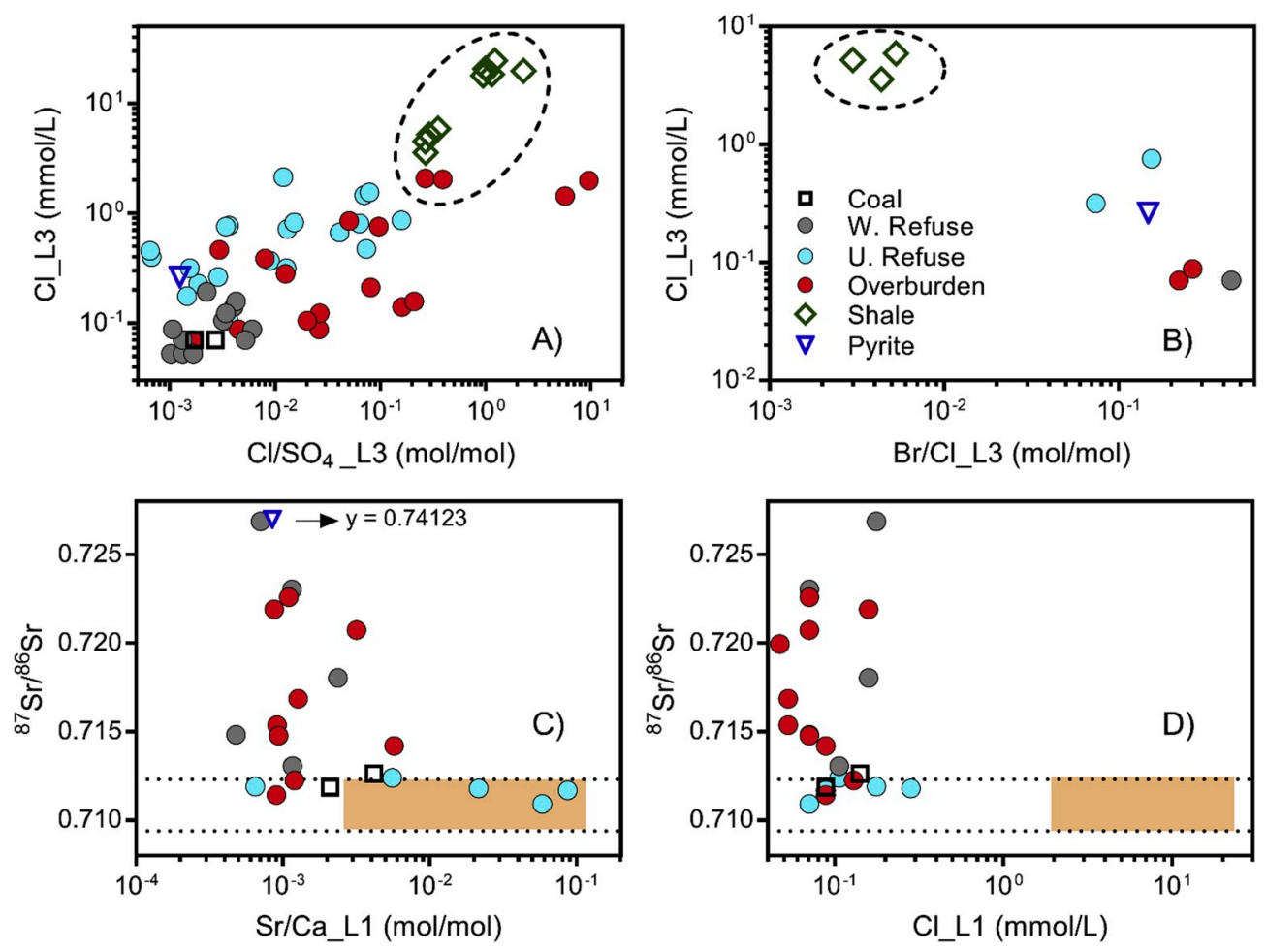

Fig. 8. Relations between sulfate or bromide and chloride to distinguish leachates of gas-bearing black shales from coal-associated rocks.

bearing strata containing pyrite and associated oxidation products; such samples produced the highest SC and the lowest pH. For Figs. SI-3 and SI-4, the DI and $\mathrm{H}_{2} \mathrm{O}_{2} \quad \mathrm{CO}_{2}$ leaches (L1 and L2, combined) were binned based on SC interval (100-1000; 1000-2000; 2000-5000; 5000-10,000; $10,000-20,000$; and $20,000-35,000 \mu \mathrm{S} / \mathrm{cm}$ ) or $\mathrm{pH}$ interval $(0.5-1.5$; $1.5-2.5 ; 2.5-3.5$; 3.5-4.5; 4.5-5.5; 5.5-6.5; 6.5-7.5; and 7.5-8.5) irrespective of rock type. The pH-dependency of concentrations of metals (e. g., Fe, Al, Cd, Co, Cu, Ni, Pb, Zn) reflected corresponding mineral or metal-oxide solubilities. The oxyanion-forming metalloids As and Se were also more soluble at lower $\mathrm{pH}$ and higher SC. Although the concentrations of all major and trace constituents generally increased with decreased $\mathrm{pH}$, the concentrations of chloride, sodium, potassium, strontium, and barium also exhibited an increase from near-neutral $\mathrm{pH}$ to alkaline $\mathrm{pH}$ values. The increased concentrations of these elements with $\mathrm{pH}$ result from dissolution of constituents, including salts, in shale samples from gas-bearing strata (Figure SI-5). Thus, despite having limited acid-forming potential, the gas-bearing shales evaluated in this study can be sources of elevated salinity.

The ability to distinguish the source(s) of salinity becomes challenging in the Appalachian Basin where coal mining, conventional oil and gas $(\mathrm{O} \& \mathrm{G})$ production, and unconventional gas production coexist. As noted above, shales produced $\mathrm{Na}-\mathrm{Cl}$ waters that were generally distinct from $\mathrm{Ca}-\mathrm{SO}_{4}$ waters produced from coal-associated rocks. Additionally, bromide, strontium isotopes $\left({ }^{87} \mathrm{Sr} /{ }^{86} \mathrm{Sr}\right)$, and radium isotopes $\left({ }^{228} \mathrm{Ra} /{ }^{226} \mathrm{Ra}\right)$ have all been used to identify the addition of O\&Gproduced water into freshwater systems (Chapman et al., 2012; Rowan et al., 2011; Johnson et al., 2015; Warner et al., 2012). The leachate chemistry from gas-producing shales (nine samples from Utica/Point Pleasant Shale plus one sample from Marcellus Shale) compared to coal mining-associated materials evaluated in this study showed that differentiation with $\mathrm{Cl}$ versus $\mathrm{Cl} / \mathrm{SO}_{4}$ molar ratio could be effective for salinity source identification (Fig. 8). Br was not a robust tracer in this study because it was below detection in most samples from coal-bearing strata (e.g., 24 of 65 samples had measurable Br in L1; 9 of 65 samples had measurable $\mathrm{Br}$ in $\mathrm{L} 3$ ). Where $\mathrm{Br}$ values were above detection limits, $\mathrm{Cl} / \mathrm{Br}$ and $\mathrm{Cl}$ were greater in the leachate from gas-bearing shale samples compared to the coal-associated rocks.

\section{Conclusions}

Increased salinization of fresh water resources is a growing concern even in water-rich regions such as the Appalachian Basin. Management of activities and industries that release TDS could reduce salinity, SC, and other measures of ionic strength of receiving waters. For coal mining, segregation and isolation of rocks that produce high levels of TDS is one obvious management strategy. To implement this strategy, a rapid and simple method to identify these rocks by quantifying TDS release is required. In regions with coal mining and other sources of TDS (e.g., coal-bed methane, oil \& gas development, road brining), source identification could also help reduce TDS release and enhance the information available to decision makers.

In this study, a rapid batch extraction method was evaluated to estimate potential for TDS release by 65 samples of rock from coal and gasbearing strata of the Appalachian Basin in the eastern U.S. Three different extractant solutions were reacted with crushed rock samples ( $20 \mathrm{~mL}: 10 \mathrm{~g}$ ) for a duration of $4 \mathrm{~h}$ : deionized water (DI), DI equilibrated with $10 \% \mathrm{CO}_{2}$ atmosphere (DI $\mathrm{CO}_{2}$ ), or $30 \% \mathrm{H}_{2} \mathrm{O}_{2}$ under $10 \% \mathrm{CO}_{2}$ $\left(\mathrm{H}_{2} \mathrm{O}_{2} \quad \mathrm{CO}_{2}\right)$. The TDS, SC, osmotic pressure, and ionic strength of the extracts were positively correlated and could be interpreted interchangeably. The $\mathrm{pH}$ of extractant blanks decreased in the order DI (6.0), DI $\mathrm{CO}_{2}$ (5.1), and $\mathrm{H}_{2} \mathrm{O}_{2} \quad \mathrm{CO}_{2}$ (2.6), which indicated the $30 \% \mathrm{H}_{2} \mathrm{O}_{2}$ was mildly acidic as well as an oxidant. The DI extractant was effective for mobilizing soluble $\mathrm{SO}_{4}$ and $\mathrm{Cl}$ salts, which are predominant sources of TDS upon initial wetting of crushed rock. The DI $\mathrm{CO}_{2}$ extractant increased the weathering of carbonates present in some samples, but did not significantly increase TDS production compared to the DI extraction when considering the whole set of samples. The $\mathrm{H}_{2} \mathrm{O}_{2} \quad \mathrm{CO}_{2}$ extractant increased the weathering of sulfides (and carbonates) and resulted in the greatest TDS production and lowest $\mathrm{pH}$ values.

Of the 65 samples, 19 had leachate chemistry data from flow-through column experiments and 35 were paired to 10 field sites with leachate chemistry data from multiple field records. When accounting for the 
mass of rock-to-volume of extractant, TDS measured in batch extractions was strongly correlated to cumulative TDS calculated from column experiments. TDS measured in batch extractions using $30 \% \mathrm{H}_{2} \mathrm{O}_{2}$ under $10 \% \mathrm{CO}_{2}$ was higher and poorly correlated to cumulative TDS calculated from upscaled column experiments. Results suggest that the cumulative water-to-rock ratio controls leachate chemistry in batch extractions using DI water or flow-through configurations using synthetic rain.

Because TDS was not reported or complete analyses of ions required to compute TDS were not available for numerous field samples, batch extractions and field measurements were compared based on SC. In contrast to column experiments, field SC was better correlated to SC measured from $\mathrm{H}_{2} \mathrm{O}_{2} \quad \mathrm{CO}_{2}$ extractions versus $\mathrm{DI}$ extractions. The field $\mathrm{SC}$ and $\mathrm{SC}$ from $\mathrm{H}_{2} \mathrm{O}_{2} \quad \mathrm{CO}_{2}$ extractions were statistically indistinguishable for 7 of 9 paired data sets while SC from DI extractions underestimated field SC in 5 of 9 cases. Compared to column leaching over months or waiting until mined rock begins weathering in the field, the rapid batch extractions of small samples are efficient and informative. The small sample size used in batch tests permits testing of specific lithologies or strata. Results were comparable among the rapid batch tests and longer-term laboratory or field data sets. Upscaling comparisons suggests that (1) weathering reactions in the field are more aggressive than DI water or synthetic rainwater extractants used in batch or column tests, and (2) a batch extraction method utilizing $30 \% \mathrm{H}_{2} \mathrm{O}_{2}$ (which is mildly acidic without $\mathrm{CO}_{2}$ enrichment) with corresponding measurements of SC could be effective for identifying rocks that will release high amounts of TDS. Additional measurements of $\mathrm{pH}, \mathrm{SO}_{4}$, and $\mathrm{Cl}$ in the extracts may be useful to identify TDS contributions from gas-bearing shale samples compared to the coal-associated rocks.

\section{Author contributions}

Luis Castillo Meza - formal analysis, writing - original draft, writing - review and editing; Charles Cravotta - formal analysis, writing original draft, writing - review and editing; Travis L. Tasker - formal analysis; Nathaniel Warner - writing - original draft, writing - review and editing; Lee Daniels - formal analysis, writing - review and editing; Zenah Orndorf - formal analysis, writing - review and editing; Tim Bergstresser - formal analysis; Amy Douglass - formal analysis; George Kimble - formal analysis; Joelle Streczywilk - formal analysis; Chris Barton - formal analysis, writing - review and editing; Stephanie Fulton - formal analysis, writing - review and editing; Aaron Thompson formal analysis, writing - review and editing; and William D. Burgos supervision, writing - original draft, writing - review and editing.

\section{Declaration of competing interestCOI}

The authors declare that they have no known competing financial interests or personal relationships that could have appeared to influence the work reported in this paper.

\section{Acknowledgments}

This research was supported by the U.S. Department of the Interior, Office of Surface Mining, Reclamation and Enforcement, Applied Science Program, grant number S16AC20082 to W.B., N.W., and C.C. L.C. was supported by the Fulbright Commission of Colombia and Universidad Pontificia Bolivariana seccional Bucaramanga. Any use of trade, firm, or product names is for descriptive purposes only and does not imply endorsement by the U.S. Government.

\section{Appendix A. Supplementary data}

Supplementary data to this article can be found online at https://doi. org/10.1016/j.apgeochem.2020.104540.

\section{References}

Agouridis, C.P., Angel, P., Taylor, T., Barton, C.D., Warner, R., Yu, X., Wood, C., 2012. Water quality characteristics of discharge from reforested loose-dumped mine spoil in eastern Kentucky. J. Environ. Qual. 41, 454-468.

ASTM, 2017. Standard Test Method for Total Carbon and Organic Carbon in Water by Ultraviolet, or Peroxide Oxidation, or Both, and Infrared Detection. ASTM International, West Conshohocken, PA. https://doi.org/10.1520/D4839-03R17.

Appelo, C., Van Loon, L., Wersin, P., 2010. Multicomponent diffusion of a suite of tracers (HTO, Cl, Br, I, Na, Sr, Cs) in a single sample of Opalinus Clay. Geochem. Cosmochim. Acta 74, 1201-1219.

Barnhisel, R., Harrison, J., 1976. Estimating Lime Requirement by a Modified Hydrogen Peroxide Potential Acidity Method. Kentucky Agricultural Experiment Station Soil Testing Laboratory, Lexington, KY.

Barrett, A.P.a.S., 2015. \$2.5 Million Settlement Reached in Dunkard Creek Fish Kill. Greene County Messenger News.

Bernhardt, E.S., Lutz, B.D., King, R.S., Fay, J.P., Carter, C.E., Helton, A.M., Campagna, D., Amos, J., 2012. How many mountains can we mine? Assessing the regional degradation of Central Appalachian rivers by surface coal mining. Environ. Sci. Technol. 46, 8115-8122.

Brady, K.B.C., Smith, M.W., Schueck, J. (Eds.), 1998. Coal Mine Drainage Prediction and Pollution Prevention in Pennsylvania. Pennsylvania Department of Environmental Protection, p. 375.

Chapman, E.C., Capo, R.C., Stewart, B.W., Kirby, C.S., Hammack, R.W., Schroeder, K.T., Edenborn, H.M., 2012. Geochemical and strontium isotope characterization of produced waters from Marcellus Shale natural gas extraction. Environ. Sci. Technol. 46, 3545-3553.

Clark, E.V., Daniels, W.L., Zipper, C.E., Eriksson, K., 2018. Mineralogical influences on water quality from weathering of surface coal mine spoils. Appl. Geochem. 91, 97-106.

Commonwealth of Pennsylvania, 2018a. Chapter 87. Surface mining of coal. Pennsylvania Code, Title 25. Environmental protection. 25 Pa. Code $\S 87$. htt ps://www.pacode.com/secure/data/025/chapter87/025_0087.pdf. (Accessed 1 March 2019).

Commonwealth of Pennsylvania, 2018b. Chapter 93. Water quality standards. Title 25. Environmental Protection. 25 Pa. Code $\S 93$. https://www.pacode.com/secure/data /025/chapter93/chap93toc.html. (Accessed 1 March 2019).

Cormier, S.M., Suter, G.W., Zheng, L., 2013a. Derivation of a benchmark for freshwater ionic strength. Environ. Toxicol. Chem. 32, 263-271.

Cormier, S.M., Suter, G.W., Zheng, L., Pond, G.J., 2013b. Assessing causation of the extirpation of stream macroinvertebrates by a mixture of ions. Environ. Toxicol Chem. 32, 277-287.

Cravotta III, C.A., 2008. Dissolved metals and associated constituents in abandoned coalmine discharges, Pennsylvania, USA. Part 1: constituent quantities and correlations. Appl. Geochem. 23, 166-202.

Cravotta, C.A., Brady, K.B.C., 2015. Priority pollutants and associated constituents in untreated and treated discharges from coal mining or processing facilities in Pennsylvania, USA. Appl. Geochem. 62, 108-130.

Daniels, W., Beck, M., Eick, M., Orndorff, Z., 2009. Predicting contaminant leaching potentials for Central Appalachian overburden and coal refuse materials. Final Rep. OSM Appl. Sci. Res. Progr. 55.

Daniels, W., Zipper, C., Orndorff, Z., 2014a. Predicting release and aquatic effects of total dissolved solids from Appalachian USA coal mines. Int. J. Coal Sci. Technol. 1, 152-162.

Daniels, W.L., Orndorff, Z., Ross, C., Koropchak, S., Zipper, C., Evans, D., Eick, M., Cooperator, F., Nash, W., 2014b. Correlation of TDS release potentials with field leaching behaviors for appalachian coal mine spoils and coarse refuse. Final Rep. OSM Appl. Sci. Res. Progr. 73.

Daniels, W., Zipper, C., Orndorff, Z., Skousen, J., Barton, C., McDonald, L., Beck, M., 2016. Predicting total dissolved solids release from central Appalachian coal mine spoils. Environ. Pollut. 216, 371-379.

Donovan, J., Denicola, T., Ziemkiewicz, P., Light, D., 2015. Bromide in Underground Mine Water of the Pittsburgh Coal: West Virginia Mine Drainage Task Force Symposium, p. 21.

Donovan, J.J., Leavitt, B.R., 2004. The Future of Mine Water Discharges from Underground Coal Mines of the Pittsburgh Coal Basin, WVPA, Proceedings of National Meeting of the American Society of Mining and Reclamation and the 25th West Virginia Surface Mine Drainage Task Force Meeting. Morgantown, WV. ASMR, Lexington, pp. 518-528.

Fishman, M.J., Friedman, L.C., 1989. Methods for determination of inorganic substances in water and fluvial sediments. US Dep. Interior Geol. Survey 437-438.

Hammarstrom, J.M., Brady, K.A., Cravotta, C.A., 2005. Acid-rock drainage at Skytop, Centre county, Pennsylvania. US Geological Survey.

Hammarstrom, J.M., Cravotta III, C.A., Galeone, D.G., Jackson, J.C., Dulong, F.T., 2009. Characterization of rock samples and mineralogical controls on leachates. Off. Surf. Mining Reclamat. Enforc. 51.

Haynes, W., 2013. CRC Handbook of Chemistry and Physics, 94th edn. CRC Press.

Hornberger, R., Brady, K., 2009. The Development and Interpretation of the ADTI-WP2 Leaching Column Method (Kinetic Test Procedure for the Prediction of Coal Mine Drainage Quality) EPA Method 1627. PA Department of Environmental Protection, Pennsylvania State University, CSC Dyncorp, US Office of Surface Mining Reclamation and Enforcement. USGS Google Scholar, US EPA.

Hornberger, R.J., Brady, K.B., Cuddeback, J.E., White, W.B., Scheetz, B.E., Telliard, W.A., Parsons, S.C., Loop, C.M., Bergstresser, T., McCracken, C., 2004. Refinement of ADTI-WP2 standard weathering procedures, and evaluation of particle size and surface area effects upon leaching rates: Part 1: laboratory evaluation of method 
performance. In: Proceedings of 2004 National Meeting of the American Society for Mining and Reclamation, pp. 916-947.

Johnson, J.D., Graney, J.R., Capo, R.C., Stewart, B.W., 2015. Identification and quantification of regional brine and road salt sources in watersheds along the New York/Pennsylvania border, USA. Appl. Geochem. 60, 37-50.

Kaushal, S.S., Groffman, P.M., Likens, G.E., Belt, K.T., Stack, W.P., Kelly, V.R., Band, L.E., Fisher, G.T., 2005. Increased salinization of fresh water in the northeastern United States. Proc. Natl. Acad. Sci. Unit. States Am. 102, 13517-13520.

Kaushal, S.S., Likens, G.E., Pace, M.L., Utz, R.M., Haq, S., Gorman, J., Grese, M., 2018. Freshwater salinization syndrome on a continental scale. Proc. Natl. Acad. Sci. Unit. States Am., 201711234

Kiyosawa, K., 2003. Theoretical and experimental studies on freezing point depression and vapor pressure deficit as methods to measure osmotic pressure of aqueous polyethylene glycol and bovine serum albumin solutions. Biophys. Chem. 104, 171-188.

McCleskey, R.B., Nordstrom, D.K., Ryan, J.N., Ball, J.W., 2012. A new method of calculating electrical conductivity with applications to natural waters. Geochem. Cosmochim. Acta 77, 369-382.

Noll, D.A., Bergstresser, T.W., Woodcock, J., 1988. Overburden Sampling and Testing Manual. Pennsylvania Department of Environmental Resources, Harrisburg, PA.

O'Shay, T., Hossner, L.R., Dixon, J.B., 1990. A modified hydrogen peroxide oxidation method for determination of potential acidity in pyritic overburden. J. Environ. Qual. 19, 778-782.

Odenheimer, J., Skousen, J., McDonald, L., Vesper, D., Mannix, M., Daniels, W., 2015. Predicting release of total dissolved solids from overburden material using acid-base accounting parameters. Geochem. Explor. Environ. Anal. 15 (2-3), 131-137.

Orndorff, Z., Daniels, W.L., Beck, M., Eick, M., 2010. Leaching potentials of coal spoil and refuse: acid-base interactions and electrical conductivity. In: Proceedings 27th National Meeting of the American Society of Mining and Reclamation (ASMR). ASMR, pp. 736-766.

Orndorff, Z.W., Daniels, W.L., Zipper, C.E., Eick, M., Beck, M., 2015. A column evaluation of Appalachian coal mine spoils' temporal leaching behavior. Environ. Pollut. 204, 39-47.

Parkhurst, D.L., Appelo, C., 2013. Description of input and examples for PHREEQC version 3-A computer program for speciation, batch-reaction, one-dimensional transport, and inverse geochemical calculations.

Phan, T.T., Capo, R.C., Stewart, B.W., Graney, J.R., Johnson, J.D., Sharma, S., Toro, J. 2015. Trace metal distribution and mobility in drill cuttings and produced waters from Marcellus Shale gas extraction: uranium, arsenic, barium. Appl. Geochem. 60, 89-103.

Pond, G.J., Passmore, M.E., Borsuk, F.A., Reynolds, L., Rose, C.J., 2008. Downstream effects of mountaintop coal mining: comparing biological conditions using familyand genus-level macroinvertebrate bioassessment tools. J. North Am. Benthol. Soc 27, 717-737.
Rowan, E., Engle, M., Kirby, C., Kraemer, T., 2011. Radium content of oil- and gas-field produced waters in the northern Appalachian Basin (USA)—summary and discussion of data. U.S. Geol. Survey Sci. Investig. Rep. 2011-5135.

Sena, K., Barton, C., Angel, P., Agouridis, C., Warner, R., 2014. Influence of spoil type on chemistry and hydrology of interflow on a surface coal mine in the eastern US coalfield. Water Air Soil Pollut. 225, 1-14.

Skousen, J., Renton, J., Brown, H., Evans, P., Leavitt, B., Brady, K., Cohen, L., Ziemkiewicz, P., 1997. Neutralization potential of overburden samples containing siderite. J. Environ. Qual. 26, 673-681.

Skousen, J., Simmons, J., McDonald, L., Ziemkiewicz, P., 2002. Acid-base accounting to predict post-mining drainage quality on surface mines. J. Environ. Qual. 31, 2034-2044.

Sobek, A.A., Schuller, W.A., Freeman, J.R., Smith, R.M., 1978. Field and Laboratory Methods Applicable to Overburdens and Minesoils. Industrial Environmental Research Laboratory, Office of Research and Development, US Environmental Protection Agency EPA-600/2- 78-054. U.S. Gov. Print. Office, Washington, DC.

Stewart, B.W., Chapman, E.C., Capo, R.C., Johnson, J.D., Graney, J.R., Kirby, C.S., Schroeder, K.T., 2015. Origin of brines, salts and carbonate from shales of the Marcellus Formation: evidence from geochemical and Sr isotope study of sequentially extracted fluids. Appl. Geochem. 60, 78-88.

Tasker, T.L., Piotrowski, P.K., Dorman, F.L., Burgos, W.D., 2016. Metal associations in Marcellus shale and fate of synthetic hydraulic fracturing fluids reacted at high pressure and temperature. Environ. Eng. Sci. 33, 753-765.

Tasker, T.L., Warner, N.R., Burgos, W.D., 2019. Forensic Fingerprinting Using Geochemical and Isotope Analysis of Produced Water from the Utica and Point Pleasant Shale, Appalachian Basin. Environmental Science \& Technology in revision May 2019.

Timpano, A.J., Schoenholtz, S.H., Zipper, C.E., Soucek, D.J., 2010. Isolating Effects of Total Dissolved Solids on Aquatic Life in Central Appalachian Coalfield Streams: 2010. National Meeting of the American Society of Mining and Reclamation, Pittsburgh, PA, pp. 1284-1302.

Timpano, A.J., Schoenholtz, S.H., Soucek, D.J., Zipper, C.E., 2015. Salinity as a limiting factor for biological condition in mining-influenced Central Appalachian headwater streams. J. Am. Water Resour. Assoc. 51, 240-250.

Wang, Y., 2014. Source Water Quality Assessment and Source Water Characterization for Drinking Water Protection. Carnegie Mellon University, Dissertations.

Warner, N.R., Jackson, R.B., Darrah, T.H., Osborn, S.G., Down, A., Zhao, K., White, A., Vengosh, A., 2012. Geochemical evidence for possible natural migration of Marcellus Formation brine to shallow aquifers in Pennsylvania. Proc. Natl. Acad. Sci. Unit. States Am. 109, 11961-11966.

Ziemkiewicz, P., 2015a. Chloride and Bromide in Waters Associated with Production of Shale Gas, Coal Bed Methane, and Coal in the Northern Appalachian Basin: 2015. International Pittsburgh Coal Conference, Pittsburgh, PA, 2 pp.

Zipper, C.E., Krenz, R.J., Clark, E.V., Daniels, W.L., 2015. Evaluation of TDS concentrations from valley fills, West Virginia mine drainage task force symposium. Morgantown 3 pp.. 